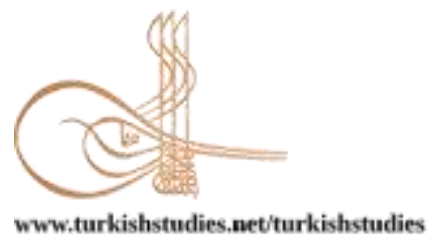

Turkish Studies

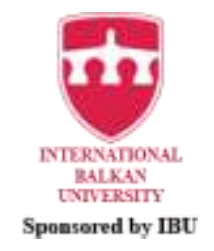

\title{
Ayvalık Cunda Adası'ndaki Panagia (Koimesis Theotokou) ve Agios Panteleimon Kiliselerinin Mimari Tarihi ve Mekânsal Dönüşümü
}

\author{
The Architectural History and Spatial Transformation of Panagia (Koimesis Theotokou) and Agios \\ Panteleimon Churches on Cunda Island of Ayvalık
}

\author{
Hasan Sercan Sağlam*
}

\begin{abstract}
Ayval1k in the northwestern coast of Turkey is renowned with its characteristic architectural heritage from the 19th-20th centuries. While some of its landmarks were recently restored and received new functions, some were lost in time due to natural and man-made damages. Correspondingly, this article focuses on two Greek Orthodox churches on Cunda / Alibey Island in Ayvalık that were demolished in the mid-20th century, namely Panagia and Agios Panteleimon. The literature that mostly relies on scant secondary sources and old photographs has very limited information about their long durée from an urban and architectural perspective. Meanwhile, the plots of both churches appear as abandoned ruin sites within the urban fabric of Cunda today. In this article, the architectural history of the aforementioned buildings were substantially elaborated through a group of late 19th century archival documents with plans and drawings that were studied for the first time. In addition, published primary sources were considered and discussed. Then, their current preservation status were demonstrated after the most recent Cunda conservation master plan and listing registries. Major outcomes have displayed that the timeline as well as architecture of Panagia and Agios Panteleimon significantly differ from what has been previously put forth by the literature. There were successive alterations with intriguing irregularities until their final appearances by the end of the 19th century. Furthermore, their plots were almost completely omitted from the conservation point of view and are under risk, though a multilayered architectural heritage is evident beneath the high debris and vegetation.
\end{abstract}

Structured Abstract: The town of Ayvalık in the Balıkesir Province of Turkey has numerous examples of the traditional architecture from the 19th-20th centuries that approximately 2000 of them were listed as monument by the national legislation. It was predominantly inhabited by ethnic Greeks during the Ottoman Empire period but had a full demographical change due to the 1923 population exchange between Turkey and Greece. This incident also caused impact on the built environment, as a significant portion of the architectural heritage was not used again and neglected. After constant damages in time, the demolished landmarks naturally caught less scholarly attention than the extant ones. Two of them were the churches of Panagia (Koimesis Theotokou) and Agios Panteleimon on Cunda / Alibey Island (formerly Yunda / Moschonisi) of Ayvalık, which were razed to the ground in the mid-20th century. The literature hardly demonstrated the multifaceted architectural history and spatial transformation of both churches. In addition, their current situation was not handled from the conservation point of view. Thus, the archaeological value of

\footnotetext{
* Dr., Koç Üniversitesi Anadolu Medeniyetleri Araştırma Merkezi (ANAMED)

Dr., Koç University Research Center for Anatolian Civilizations (ANAMED)

ORCiD 0000-0002-6621-0436

saglam.h.sercan@gmail.com

Cite as/ Atıf: Sağlam, H. S. (2021). Ayvalık Cunda adası'ndaki Panagia (Koimesis Theotokou) ve Agios Panteleimon

kiliselerinin mimari tarihi ve mekânsal dönüşümü. Turkish Studies, 16(3), 989-1017.
} https://dx.doi.org/10.7827/TurkishStudies.50683

Received/Geliş: 01 April/Nisan 2021

Accepted/Kabul: 20 June/Haziran 2021

Checked by plagiarism software

Published/Yayın: 25 June/Haziran 2021

CC BY-NC 4.0 
their plots as well as the architectural heritage itself were omitted. This article aims to elaborate the rather undiscovered urban and architectural aspects of both churches and to demonstrate a new chronology for them in the 19th century. The study also discusses their current preservation status for potential solutions in future.

Speaking generally, Panagia and Agios Panteleimon were almost completely omitted by the scientific literature about Ayvalık and Cunda Island. Available information primarily came from two nonacademic books written by Sitsa Karaiskaki and Ali Onay, who simply witnessed the churches by the 1920s and mentioned an incoherent secondary narrative about the architectural history of Panagia in particular. They were most recently taken into account by the technical study of Dimitros E. Psarros, who generously quoted them and also added few superficial interpretations about the churches after distant old photographs. The works of Eustratios I. Drakos as a witness from the 19th century were considered only with a limited extent due to an unknown reason. The aforesaid narrative, actually an urban myth derived from the bell of Panagia substantially falsified its own architectural history. Furthermore, Agios Panteleimon was basically attributed to the architect Emmanuel Kounas due to stylistic similarities and its ultimate reconstruction was excluded. Conclusions eventually relied on indirect accounts derived from Karaiskaki and Onay, few old photographs and brief assumptions, which appear as fundamental facts about the monuments today. On the other hand, this article displays successive reconstructions and alterations of both churches, which provided their final known appearance, though not mentioned in the literature. It includes the urban and architectural extent of those works for a detailed spatial chronology in the late 19th century. The study considers archival documents and critically discusses available primary sources. It also tackles present conservation issues for the first time with a specific architectural focus on Panagia and Agios Panteleimon.

For the research background of this article, the main primary sources that were consulted can be listed as four sets of documents from the Ottoman Archives (BOA) with precise descriptions, plans and drawings dated 1882-1896; official annals (Salname) from 1884-1903; three volumes about Cunda Island by Eustratios I. Drakos from 1888-1895; the bell of Panagia dated 1863 in the Bergama Archaeology Museum; an audit report dated 1913 about the churches of Cunda; and archival photographs from the first half of the 20th century. Modern literature as well as later narratives were critically discussed after the primary sources. For contemporary conservation issues, official master plans and listing registries were taken into account. They were further supported by a small field survey in order to demonstrate the current situation in Cunda. The main limitations appeared as inaccessible parts due to vegetation and high debris that cover the ruins.

It was seen that the architectural history of Panagia and Agios Panteleimon had crucial differences when compared to the existing literature that lacked archival sources. After a reassessment of the legendary foundation of Panagia on an empty area in 1863 by a Turk called "Ali Ağa," it was noticed that the church was present since the 18th century and the aforesaid tale was seemingly an urban myth, simply derived from the inscription of the Panagia's bell. 1863 was in fact the year when Panagia received its first belfry and the bell in question. Yet, it was completely reconstructed in 1883 but the old bell was continued to be used. Moreover, the ultimate reconstruction of Agios Panteleimon was happened not in 1882 as formerly stated but in 1896, with a neoclassical design by the master builder Onoufrios Kouvaras. Crucial architectural mismatches were detected between the official reconstruction plans and church buildings that appear on old photographs. The plots of Panagia and Agios Panteleimon evidently had a multilayered archaeological character due to repetitive reconstructions, which were not precisely superposed on previous foundations and were slightly shifted. As their final demolitions in 1954 were for obtaining building materials instead of a complete areal clearance, the ruins of multiple church foundations from different construction phases were presumably preserved under the high debris and vegetation there; also the annexes for priests, courtyard pavements, and especially the chapel and the holy spring of Panagia. Within the contexts of the construction law transgression and shifted foundations during later reconstructions, it can be said that Panagia and Agios Panteleimon have parallels with some cases from the nearby Lesbos.

The preservation status of both churches have crucial deficiencies, as the most recent conservation master plan for Cunda dated 1994 completely ignored them and designated their plots as park and residence areas. They are under risk against treasure hunters and new urban development, as the settlement lacks a conservation master plan today. The plot of Agios Panteleimon is still unlisted and the one of Panagia was individually listed in 2020. After necessary conservation decisions, the ruins can be carefully unearthed and with the help of technological advances like digital surveys and virtual reconstructions, the plots might be converted into thematic modern archaeology museum sites. 
Keywords: Urban History, Architectural History, Churches, Ayvalık, Cunda Island.

Öz: Türkiye'nin kuzeybatı kıyı kesiminde bulunan Ayvalık, 19-20. yüzyıllara tarihlenen karakteristik mimari mirasıyla bilinmektedir. Anıtlarından bir kısmı yakın zamanda restore edilerek yeni işlevler kazanmış olsa da bazıları doğa ve insan kaynaklı düzenli tahribatlar nedeniyle zaman içerisinde kaybolmuştur. İlintili olarak bu makale, Ayvalık'a bağlı Cunda / Alibey Adası'ndaki iki eski Rum Ortodoks kilisesi olan ve 20. yüzyılın ortalarında yıktırılmış Panagia ve Agios Panteleimon'u ele almaktadır. Mevcut literatür muğlak ikincil kaynaklara ve de eski fotoğraflara dayandığı üzere bu kiliselerin uzun yaşamına dair kentsel ve mimari bağlamda oldukça sınırlı bilgiye sahiptir. Bu arada her iki yapının da arsası günümüz Cunda kent dokusu içerisinde terk edilmiş ve viran halde durmaktadır. Bahis konusu kiliselerin mimarlık tarihi, plan ve çizimler içeren ve ilk kez bu makalede etraflıca ele alınan geç 19. yüzyıl tarihli arşiv belgeleri yoluyla önemli ölçüde detaylandırılmıştır. Ayrıca yayımlanmış birincil kaynaklar da göz önüne alınarak tartışılmışıı. Daha sonra bu yapıların mevcut korunma durumu, en güncel Cunda koruma imar planı ve tescil kayıtları üzerinden ortaya konmuştur. Başlıca sonuçlar, Panagia ve Agios Panteleimon'un kronoloji ve mimarisinin daha önce literatür tarafindan ortaya konulandan önemli ölçüde farklı olduğunu göstermiştir. Bu yapılar, 19. yüzyılın sonundaki nihai görünümlerine değin art arda ve şaşırtıcı düzensizlikler barındıran değişikliklere uğramıştır. Ayrıca arsaları koruma açısından neredeyse tamamen ihmal edilmiş durumda olup risk altındadır. Lakin yüksek moloz ve bitki örtüsünün altında çok katmanlı bir mimari mirasın bulunduğu aşikârdır.

Anahtar Kelimeler: Kent tarihi, Mimarlık Tarihi, Kiliseler, Ayvalık, Cunda Adası.

\section{Giriş}

Bir yerleşimin ayrıntılı kültürel miras envanterine sahip olunması, karar alıcıların daha hassas koruma amaçlı imar planları hazırlamalarını sağlayacağı üzere kent dokusu içerisinde zamanla kaybolmuş kalıntıların yeni imar çalışmaları karşısında kurtulma şansını da artırmaktadır. Tarihi nitelikteki anıt eserlerin her birinin taşıdığı evrensel kültür mirası değerine mutlak surette sahip çıkılmasının gerekliliği kadar bu yapıların yarattığı kültürel, ekonomik ve turistik değerler de tartışmasızdır. Başlangıç noktası olarak da kayıp yapıların yerlerini tespit etmek ve onlara dair güvenilir bilimsel bilgi ortaya koymak, korumada belirleyici rol oynamaktadır. Bu nedenle birincil kaynakların kentsel ve mimari perspektiften titizlikle değerlendirilmesi, yalnızca günümüz teknolojisinin ileri düzey belgeleme ve koruma yöntemlerine yeni uygulama alanları sunmakla kalmayıp herhangi bir planlama kararı öncesinde kente dair ayrıntılı arkeolojik veri sağlamaktadır. Bu bağlamda Ağır'ın (2010) "Bilmek, korumanın ilk adımıdır" görüşü, somut kültürel miras araştırmalarının önemini vurgulamaktadır. İlintili olarak bu makale, Ayvalık'a bağlı Cunda Adası'ndaki iki yıkık Rum Ortodoks kilisesi olan Panagia (Koimesis Theotokou) ve Agios Panteleimon'u mimarlık tarihi ve koruma bağlamında ele almaktadır.

Geneli 19-20. yüzyıla tarihlenen ve günümüzde yaklaşık 2000 adet tekil örneği tescilli vaziyetteki yapılaşmış çevresiyle meşhur Ayvalık'a bağlı Cunda Adası, şehircilik ve mimarlık ölçeklerinde birçok bilimsel çalışmaya konu edilmiştir (Balıkesir Valiliği, 2010). Öte yandan adadaki mimari mirasa yönelik uygulama çalışmaları da son yıllarda ivme kazanmıştır. Örneğin mevcut dini anıtlardan Aşıklar Tepesi'ndeki Agios Ioannis Şapeli 2007'de, Pateriça'daki Agios Dimitrios ta Selina (Ayışığı Manastırı) 2012'de, ve Cunda yerleşim merkezindeki Taksiarkhis Kilisesi de 2014'te restore edilerek çeşitli kültürel fonksiyonlarla kullanıma açılmıştır. Aynı esnada adadaki birçok geleneksel konut da yenilenmiş olup, Cunda'nın kültür mirası ve turizmi yönünden çok zengin potansiyelli bir tarihi yerleşim merkezine sahip olduğunu söylemek mümkündür (Yaylal1-Gençer, 2007; 2014). Oysa tüm Ayvalık genelinde, zaman içerisinde harap olarak unutulmuş ve adeta yeniden keşfedilmeyi bekleyen daha birçok anıt eser bulunmaktadır. Bu çalışmada incelenen Panagia ve Agios Panteleimon Kiliseleri ise Cunda Adası'yla ilgili bilimsel araştırmaların büyük bir bölümünde ya ortadan kaybolmuş yapılar olarak basitçe belirtilmiş, ya da tümden yok sayılmıştır. Ayrıca güncel koruma politikaları tarafından da ihmal edilmiştir. 
Literatürde, Cunda yerleşiminin 19. yüzyıla kadarki kent tarihine dair detaylı bilgi mevcut değildir. Yine de buranın yerlilerinden bir öğretmen ve araştırmacı yazar Eustratios I. Drakos'un (1852-1929) adanın tarihi, özellikle de kilise tarihine yönelik neredeyse bütünüyle arşiv belgeleri ve birincil tanıklıklara dayanan çalışmaları (Tsitimaki, 2020: 339-340), 18. yüzyılın sonundan 19. yüzyılın sonuna kadar güvenilir bilgi sağladığı üzere bu makale kapsamında titizlikle incelenmiştir. Panagia ve Agios Panteleimon'a Yorulmaz (2004: 167-168) ile Tsitimaki (2007: 485) herhangi bir detay vermeden çok kısaca değinmiş; Şahin Güçhan (2008: 54) ile Kaptan vd. (2019: 74-77) ise sadece Panagia'nın yaklaşık konumuyla bazı eski fotoğraflarını yayımlamıştır.

Cunda'ya dair en güncel ve kapsamlı bir tür derleme olan Psarros (2017) ise temelde, bu kiliselere hala ayaktayken oldukça farklı dönemlerde tanıklık etmiş Drakos (1888; 1895a; 1895b), Karaiskaki (1973) ve Onay'ın (2000a) ifadelerini kabaca derlemiş ve bazı yüzeysel yorumlamalarda bulunmuştur. Özellikle de birincil tanıklardan Drakos'un (1888; 1895a; 1895b) tuhaf şekilde farklı çalışmalarının adeta satır aralarına dağılmış önemli ifadelerini ihmal eden Psarros'un (2017) derlemesi, eski fotoğraflar ve Panagia için bir vaziyet planı krokisiyle desteklenmiştir. Bunların yanında Osmanlı Arşivleri belgeleri gibi destekleyici birincil kaynaklar ve en başta da eleştirel bir tartışmadan yoksundur. Dolayısıyla kiliselerin mimarlık tarihi ilgisindeki bazı temel meseleler oldukça muğlak kalarak basitçe Karaiskaki (1973) ve Onay'ın (2000a) şüpheli ikincil aktarımları üzerinden karara bağlanmıştır. Literatürdeki tüm bu boşluklarla ilintili olarak her iki kilisenin de mevcut koruma durumuna yönelik birtakım ihmaller söz konusudur.

$\mathrm{Bu}$ makalenin teorik önemine değinilecek olunursa, Cunda Adası'ndaki iki yıkık Rum Ortodoks kilisesi olan Panagia ve Agios Panteleimon, 19. yüzyıl sonlarına tarihlenen Osmanlı Arşivleri (BOA) belgeleri ve yayımlanmış bazı diğer birincil kaynaklar yoluyla, kentsel ve mimari perspektiften ilk kez ayrıntılı olarak ele alınmıştır. Kiliselere dair bazı mimari belirsizliklerin açıklı̆ga kavuşturulması ve atıl durumdaki arsalarının çok katmanlı arkeolojik potansiyelinin ortaya konulması amaçlanmıştır. Ayrıca yukarıda listelenen tüm tanıklıkların eleştirel bir yeniden değerlendirmesi yapılmıştır. Makale, son olarak da koruma uygulamalarına dair yönüyle, gelecekte somut adımlar atılarak çözümler geliştirilmesi umuduyla kiliselerin bugünkü korunma durumunu tartışmış, basit bir saha tespiti ve bazı önerilerle de bunu desteklemiştir.

Başlıca sonuçlara göre Panagia ve Agios Panteleimon'un mimari kronolojisi, literatürde daha önce belirtilenden çok farklıdır. Kiliseler 19. yüzyıl boyunca, nihai görünümlerine değin arka arkaya ve çokça düzensizliklere sahip mimari değişikliğe uğramıştır. Bunlara ek olarak arsaları koruma bağlamında atıl durumdadır ve savunmasız halde risk altındadır. Buralardaki yüksek moloz yığını ve bitki örtüsünün altında çok katmanlı kalıntıların bulunduğu öngörülmektedir.

\section{Yerleşimin Kısa Tarihi}

Balıkesir'e bağlı Ayvalık'ın en büyük adası olan Cunda / Alibey, günümüzde ilçenin Mithatpaşa ve Namıkkemal mahallelerini oluşturmaktadır. Kuzey Ege'de, Edremit Körfezi içerisinde yer alan ada, Osmanlı döneminde Yund Adası / Yunda (Türkçe) ve Moskhonisi / Moskhonisos (Yunanca) adlarına sahipti (başvurulan birincil kaynağa istinaden makalede her iki isim de kullanılacaktır). Adanın ana yerleşimi de önceden yine aynı iki isimle anılmaktaydı. Yaklaşık 500 metre genişlik ve 600 metre uzunluğa sahip tarihi yerleşim merkezi, adanın güney sahil şeridiyle buranın kuzeydoğusundaki iki küçük tepe boyunca uzanmaktadır. Buradan bağımsız Por(d)oselene / Nesos antik kenti ise adanın güneydoğu bölümüne konumlandırılmakta olup tarihi kaynaklara ve arkeolojik verilere göre sonradan terk edilmiş bir Helenistik-Roma yerleşimiydi (Özgen, 2017).

Pîrî Reis, 1525 itibariyle Yund Adaları'nda bir yerleşim yerinden söz etmeyip yalnızca bazı coğrafi yapıları kısaca belirtmiştir (Pîrî Reis, 2013: 42). 1530 ve 1574 tahrirleri Yund Adası'nı Ayazmend (Altınova) Sancağı altında bir koruluk olarak göstermekte, ayrıca buradaki orman alanları, tımar arazileri ve tarım ve hayvancılık faaliyetlerinden bahsetmektedir (Anonim, 1995: 
188, 279-286; Sevim, 1993). 1582'de Ayazmend sakinlerinin Yund Adasi'ndaki hayvancilik faaliyetlerinin, buradaki ahalinin tarım ürünlerine zarar verdiği kaydedilmiş ve Midilli Beyinden buna mani olması istenmiştir (BOA, A.DVNS.MHM.d, 47-284, H-20-04-990). 1603 itibariyle Midilli Sancağı'na bağlı adada küçük bir Rum yerleşiminden ve tahsil edilen cizyeden söz edilmektedir (BOA, MAD.d, 14773, H-29-09-1011). Yund Adası'na dair 1666, 1694 ve 1697 tarihli cizye kayıtları da yerleşimdeki gelişmeyi işaret etmektedir (BOA, İE.EV, 18-2194, H-13-111076; AE.SAMD.II, 11-1154, H-24-10-1105; A.DVNS.MHM.d, 110-935, H-20-05-1109). 1718 tarihli ve Patrik III. Ieremias (1716-1726) imzalı bir dilekçe, Yund Adası papazlarından Angelos'tan bahsetmekte, dolayısıyla ada yerleşiminde kilise mevcudiyeti anlaşılmaktadır (BOA, İE.BH, 13-1183, H-29-12-1130).

Herhangi bir kaynak göstermese dahi Drakos'un (1888: 16; 1895a: 19) adadaki yeni yerleşimin 1580'i takip eden bir süreçte kurulduğuna yönelik iddiası, yukarıda değinilen Osmanlı arşiv kaynaklarıyla uyumludur. Yine Drakos'un (1888: 12-13; 1895a: 15) tahminine göre bu yerleşimin merkezi Agios Ioannis Şapeli, Agia Triada Kilisesi ve Agios Panteleimon Kilisesi'nin bulunduğu Aşıklar Tepesi'dir. Psarros (2017: 304) da 16. yüzyıl sonundan başlayarak kiliseler üzerinden tahmini bir kent kronolojisi önermektedir ve yerleşimin Aş̧klar Tepesi'ndeki Agia Triada Kilisesi'nden yayılmak suretiyle bir gelişme gösterdiğini iddia etmektedir. Netice itibariyle tüm bunlar henüz birer varsayımdır ve bu özel mesele daha detaylı şehircilik araştırmalarına ihtiyaç duymaktadır.

Agia Triada, Agios Dimitrios, Panagia, Taksiarkhis ve Agios Panteleimon kiliseleri ile aynı adı taşıyan beş ana mahalle 19. yüzyıla kadarki süreçte oluşmuş, bu yüzyılın sonunda ise adadaki küçük Müslüman cemaatin tek mabedi olan Hamidiye Camii inşa edilmiştir (Psarros, 2017) (Şek. 1). Sakinlerinin 1821 Yunan İsyanı'na katılması sonucunda ada bir müddet terk edilmiş̧ olsa da sonrasında II. Mahmud tarafından ilan edilen bir af sonucu geri dönmelerine izin verilmiş ve yerleşim tekrardan kurulmuştur (Uygur ve Erim, 1948: 38-42). 26 Haziran 1821 tarihli bir Hatt-1 Hümâyunda, Yunda Adası'ndaki tüm hane ve manastırların yakılıp yıkılmak suretiyle tahrip edildiği belirtilmektedir (BOA, HAT, 942-40662, H-25-09-1236). 14 Ağustos 1825 tarihli bir diğer Hatt-1 Hümâyun ise Yunda Adası sakinleri sürgünden döndüklerinde, yerleşimdeki binalarının tamamen harap halde bulunduğunu belirtmektedir. Ayrıca cizye haricindeki yükümlülüklerinden birkaç sene muaf tutup yeniden iskan ile hayvanları için ahır ve değirmen inşası masraflarının da hazineden karşılanmasını buyurmaktadır (BOA, HAT, 901-39605, H-29-12-1240).

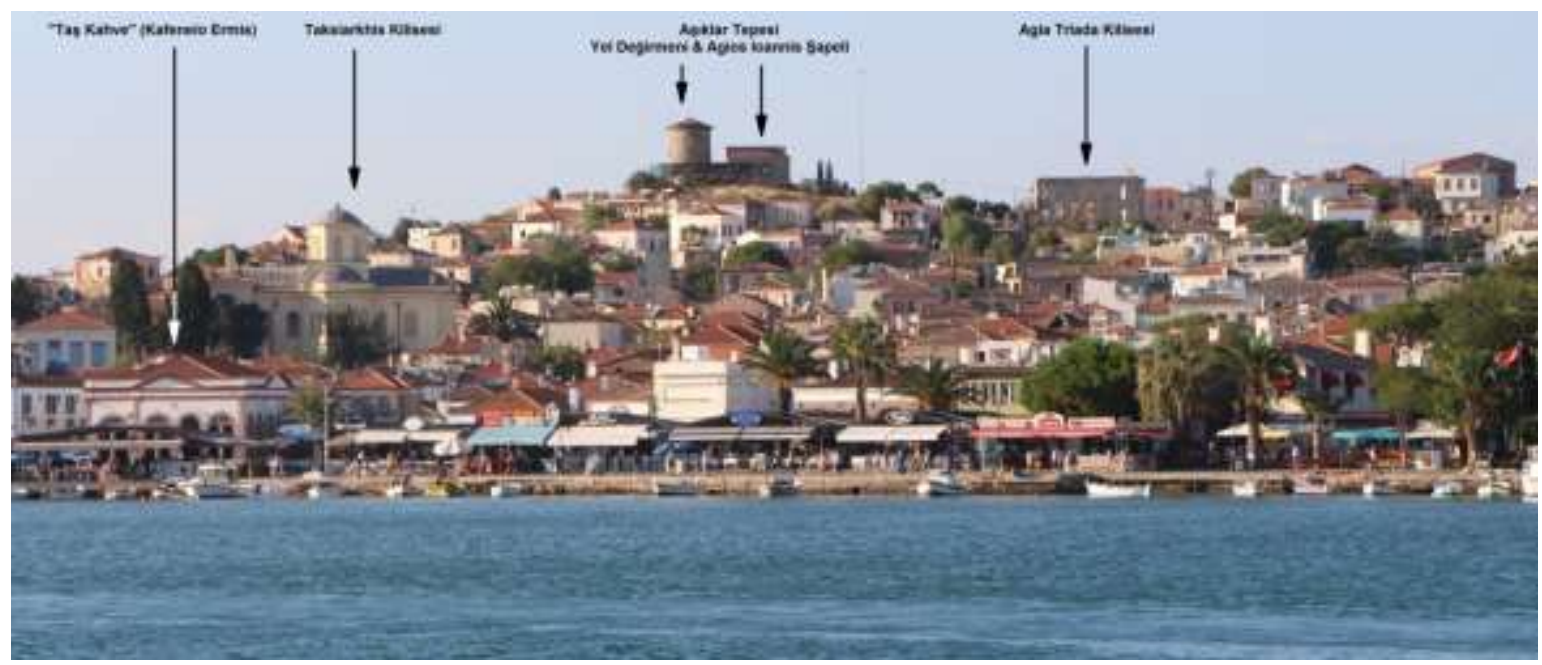

Şekil 1: Cunda / Alibey Adası tarihi yerleşim merkezinin güneyden görünümü (KEAM, 2020). 
Yunda merkezli takımada, Geç Osmanlı Dönemi itibariyle başlangıçta Cezâyir-i Bahr-i Sefîd Vilâyeti'ne bağlı Midilli Sancağı'nın Yunda / Moskhonisi kazasını oluşturmaktaydı. Ancak idari tabiiyeti ve statüsü 20. yüzyıl başına kadarki süreçte birkaç kez değiştirilmiş ve en son Hüdavendigâr Vilâyeti'ne bağlı Karesi Sancağı'nın Ayvalık kazasına bağlanmıştır (Mutaf, 2003: 77; Ünver, 2012: 103-104). Moskhonisi Piskoposluğu'nun Bizans dönemine kadar uzandığı iddia edilse de kesin bilgiler ancak 18. yüzyıla tarihlenmektedir. 1742'de Midilli Metropolitliği'nden ayrılarak İzmir Metropolitliği'ne katılmış, 1750'de ise Efes Metropolitliği'ne bağlanmıştır. 1760'ta Midilli'ye geri dönmüş ve nihayet 1763 'te yeniden İzmir'e katılmıştır. Bu esnada başpiskoposluk mertebesine yükseltilmiş ve 1922'ye kadar da faal kalmıştır (Kalamatas, 2007: 46).

Yunda / Moskhonisi 19. yüzyılın sonlarında, artan nüfus ve ticari faaliyetler sayesinde hızlı bir ekonomik gelişme göstermiştir. Cezâyir-i Bahr-i Sefîd Vilâyeti (1884: 120; 1885: 194; 1886: 192) resmi yıllıkları olan salnamelerden üçüne ve Ali Saib'e (1886: 269) göre adada 3790 Rum Ortodoks ve 37 Müslüman barındıran 1161 hane; iki erkek ve bir kız okulu; bir devlet dairesi; bir gümrük idaresi; altı manastır; beş kilise; bir deniz feneri; bir eczane; bir hekim; beş çeşme; yedi yel değirmeni; 27 kahvehane; bir tabakhane; dokuz sabun fabrikası; sekiz zeytinyağı fabrikası; ve 117 dükkân vardı. Tarımsal ve endüstriyel ürünleri tahıl, zeytin, üzüm ve sabundu. Daha sonra, Cuinet (1892: 473-474) ve diğer üç Cezâyir-i Bahr-i Sefîd Vilâyeti (1893: 292; 1898: 272; 1903: 265) salnamesi, yukarıdaki ifadelerin çoğunu doğrulamakla kalmayıp bu kez 5500 nüfus ve 1371 haneden söz etmektedir. Ayrıca adada fazladan bir otel; iki gazino; iki eczane; 12 sabun fabrikası; ve 194 dükkân bulunmaktadır. Limanı ise çok sayıda Osmanlı, İngiliz, Yunan ve Samos Prensliği ticaret gemisinin uğrak yeri olup ihraç edilen ürünler başlıca zeytinyağı, şarap, tuz, balık, ahtapot ve süngerdir. 1920-1921'e gelindiğinde Moskhonisi neredeyse tamamı Rum 8000 kişilik bir nüfusa sahiptir. Zengin bir piskoposluğa sahip müreffeh bir yerleşim olarak tanımlanmıştır (Simos, 1920: 49; Kontogianni, 1921: 276-278).

Türk Kurtuluş Savaşı (1919-1923) sonucunda Yunanistan ile Türkiye arasında bir nüfus mübadelesi yapılmıştır. Bu nedenle adanın demografik yapısı 1923-1924'te tümden değişikliğe uğramış ve başta Girit olmak üzere sonradan Yunanistan sınırları içerisinde kalmış eski Osmanlı topraklarından getirilen Müslüman Türkler, Ortodoks Rumların yerine Cunda'ya yerleştirilmişlerdir (Turan, 2008). Bu dramatik hadise yapılaşmış çevreyi de olumsuz etkilemiştir, zira birçok tarihi yapı terk edilmiş ve bir daha kullanılmamıştır. Doğa ve insan kaynaklı tahribatlardan dolayı da Cunda'daki mimari mirasın önemli bir kısmı zamanla harap olmuştur (Yaylalı-Gençer, 2007; 2014). Makalenin ele aldığı Panagia ve Agios Panteleimon kiliseleri 1923 öncesinde, Yunda / Moskhonisi tarihi yerleşim merkezinin beş mahallesinden ikisinin merkezini teşkil etmekteydi (Şek. 2). 


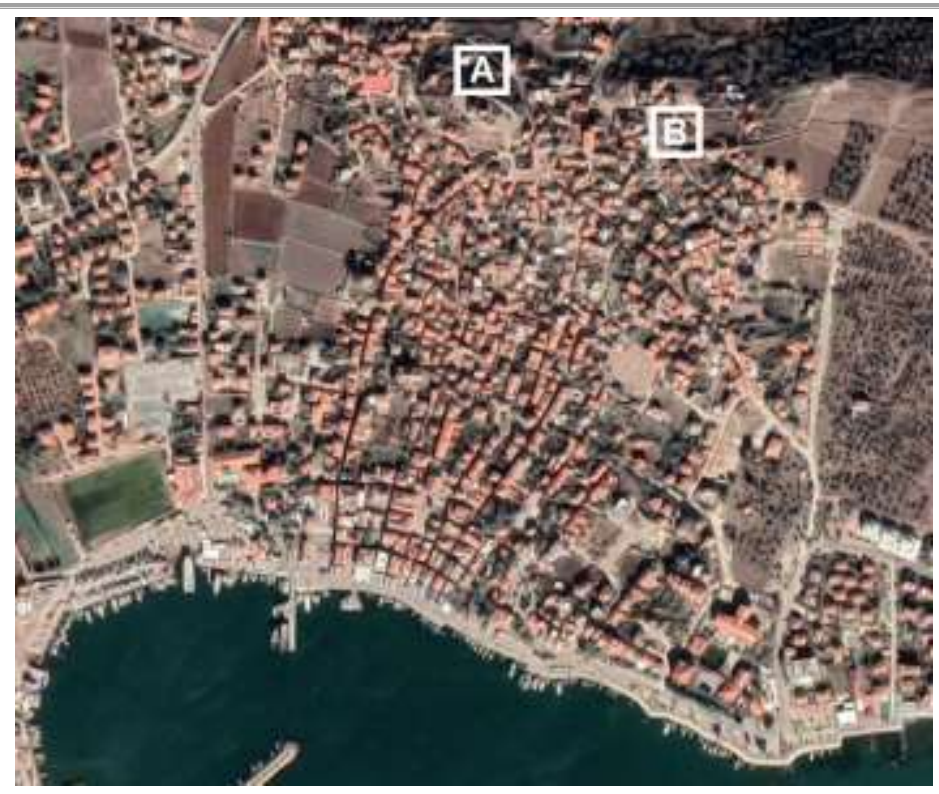

Şekil 2: Agios Panteleimon (A) ve Panagia (B) Kiliselerinin konumları (Google Haritalar, 2021).

\section{Panagia (Koimesis Theotokou) Kilisesi}

Meryem'in ölümüne atfedildiği için resmen Koimesis Theotokou ismine sahip Panagia Kilisesi'nin ilk ne zaman yapıldığ 1 bilinmemektedir. Drakos (1888: 16; 1895a: 19-20), kentin yerle bir olduğu 1821 Yunan İsyanı öncesindeki dönem için Moskhonisi kiliselerinin yine aynı konumlarda mevcut bulunduğunu kısaca belirtmekte, fakat herhangi bir isim vermemektedir. Aktardığı iki anekdot ise bu ifadeyi Panagia ilgisinde doğrulamaktadır. Öyle ki, 1768'de göreve başlamış Moskhonisi başpiskoposu I. Kirillos 1793'te öldüğünde, yerleşimin o dönem katedral kilisesi olan Panagia'da toprağa verilmişti. Mezarı, avluda bulunan iki katlı piskoposluk konutunun yanında 1821 yılına kadar korunmuştu (Drakos, 1895b: 17). Moskhonisi'deki ilkokullarla ilgili tanıklıklardan birisi de Moralı Theodoros'un, katedral kilisesi Panagia'da 1806 itibariyle yazım ve kaligrafi öğrettiğinden bahsetmektedir (Drakos, 1888: 20; 1895a: 25). Bunlara ek olarak 1819'da Moskhonisi'yi ziyaret etmiş Charles Williamson, burayı iki kiliseye ve yaklaşı 5000 nüfusa sahip şirin, küçük bir kasaba olarak tanımlamaktadır (Clogg, 1972: 660). Görünüşe bakılırsa bunlardan birisi Panagia, ötekiyse yerleşimin en eski kilisesi olduğu varsayılan Agia Triada'dır.

26 Haziran 1821 ve 14 Ağustos 1825 tarihli Hatt-1 Hümâyunlara göre Yunda Adası'ndaki tüm yapıların 1821 Yunan İsyanı nedeniyle yakılıp yıkılarak kullanılamaz hale getirildiğine değinilmişti (BOA, HAT, 901-39605, H-25-09-1236; HAT, 942-40662, H-29-12-1240). Dolayısıyla o dönem yerleşimin katedral kilisesi olan Panagia'nın bu denli kapsamlı bir tahribattan kurtulması olası değildir. 1821 sonrası ilk başpiskopos olarak ancak 1832'de atanmış Moskhonisili I. Kallinikos, buradaki yıkık kiliselerin kısa süre içinde eski yerlerinde, kabaca 1834'e kadar tekrardan inşa edilmesine öncülük etmiştir (Drakos, 1888: 24; 1895a: 29; 1895b: 23). Bu bağlamda 18. yüzyılın sonu itibariyle varlığı teyit edilebilen ve 1821 'de tahrip edildiği aşikâr katedral kilisesi Panagia'nın, bu makale kapsamında belirlenebilen ilk yeniden inşası 1832-1834 dolaylarında gerçekleştirilmiştir.

Ekim 1848'de varılan ve Patrik IV. Anthimos tasdikli bir dini mutabakatta Agia Triada, Agios Dimitrios ve Panagia'nın papazlarının bahsinin geçmesi, bu kiliselerin 1840'lar itibariyle faal olduğunu göstermektedir (Drakos, 1895b: 34-35). 1855-1872 yılları arasında başpiskoposluk yapmış İzmirli II. Kirillos dönemine denk gelen 1865 dolaylarında Moskhonisi'nin kiliselerine süslemeli, yüksek ve kâgir çan kuleleri dikilmiştir (Drakos, 1895b: 41). Aktarımda Panagia ismen belirtilmemiş olsa da bu hususta arkeolojik kanıt mevcuttur. 
Panagia Kilisesi'nin çanının 1920'lerde asıl yerindeki haline, daha sonra 1936'da Cunda'dan Ayvalık'a taşınmasına ve en son da 1970 'lerde buradan Bergama'ya götürülmesine bizzat tanıklık etmiş yerel bir kaynak olan Onay'ın (2000a; 2000b; 2010), çanın sonraki yaşamına dair ayrıntılı aktarımları, günümüzde Bergama Arkeoloji Müzesi'nde künyesiz bir şekilde sergilenmekte olan eserin esasen Panagia Kilisesi'ne ait olduğunu açıkça teyit etmektedir. Bu çanın üzerinde "A $\Lambda$ HАГА | Е. А. МПААТАZZH" (Ali-Ağa | E. A. Baltazzi) yazısı, hemen altında ise 1863 y1lı ve büyükçe bir Yunan haçı bulunmaktadır. Çanın diğer tarafındaki yazı ise Almanya'nın Bochum kentindeki çan dökümhanesini belirtmektedir (Psarros, 2017: 322). Soylu Baltazzi ailesi, Aliağa'da çokça emlak sahibiydi ve Osmanlı'nın son dönemleri itibariyle özellikle de İzmir çevresinde oldukça etkiliydi (Ortaç, 2010). Dolayısıyla Panagia Kilisesi'nin yeni çan kulesine takılacak çanı, üzerindeki yazıta göre, Aliağalı bir Baltazzi mensubu 1863 yılında hibe etmiştir (Şek. 3).

3 Kasım 1839 tarihli Tanzimat ve 18 Şubat 1856 tarihli Islahat fermanları ile Osmanlı İmparatorluğu içindeki gayrimüslimlerin ibadethanelerine getirilen mimari kısıtlamaların kademeli olarak kaldırılması düşünüldüğünde, yukarıda bahis konusu 1863 y1lı daha da anlamlı hale gelmektedir. Zira daha önce kilise ve havra gibi yapılarda kubbe ve çan kulesi inşa edilmesi kanunen yasaktı (Gümüş, 2008; Karaca, 2008). Böylece Panagia Kilisesi'nin ilk çan kulesinin, Islahat Fermanı'nı takip eden ve önceki mimari kısıtlamaların kaldırıldığı sürece denk gelen 1863 yılında, dönemin başpiskoposu II. Kirillos öncülüğünde inşa edildiği anlaşılmaktadır.

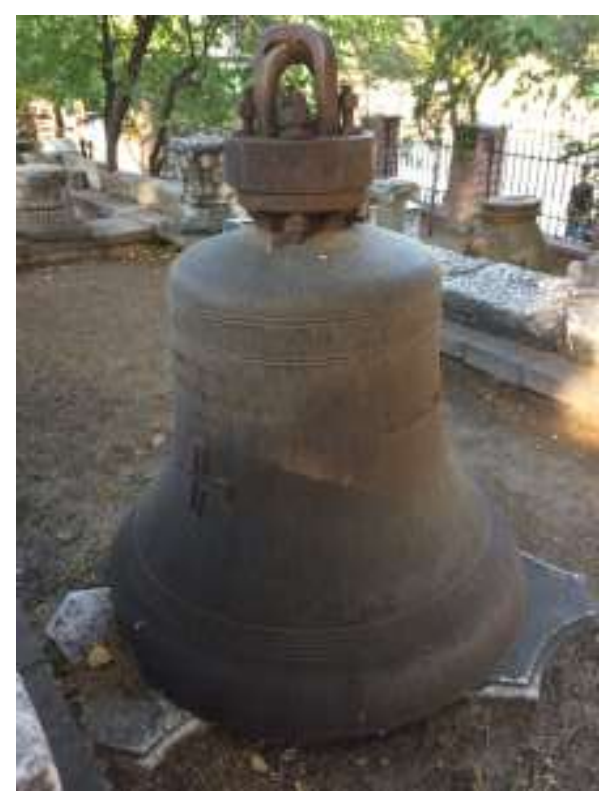

Şekil 3: Panagia Kilisesi'nin Bergama Arkeoloji Müzesi'nde sergilenen çanı (KEAM, 2020).

26 Eylül 1876 tarihinde Panagia Kilisesi'nin suları, halkın kullanımı için Moskhonisi yerleşimine yönlendirilmiştir (Drakos, 1895b: 46). Aşağıda tartışılan 8 Kasım 1882 tarihli Osmanlı soruşturması da Panagia'da bulunan bir su kaynağını teyit etmektedir. Yine Drakos'un (1888: 1819, 1895a: 22-23) kısa aktarımına göre Agia Triada Kilisesi 1865 'te inşa edilmiş; Taksiarkhis Kilisesi 1873'te inşa edilerek yeni katedral kilisesi olmuş; Agios Dimitrios, Agios Panteleimon ve Moskhonisi'nin dışındaki Agios Nikolaos mezarlık kilisesi 1882'de inşa edilmiş; ve son olarak da "çok süslü ve güzel Panagia" 1883 'te inşa edilmişti. Bu kiliselerin neredeyse tamamı yüksek çan kulelerine sahipti. Psarros'un (2017) da sıkça başvurduğu bu özet anlatıda dikkatten kaçmış asıl belirsizlik, bahis konusu kiliselerden Panagia'yı da kapsayan bazıları önceden beri mevcut bulunsa dahi ilgili işlerin bir "yeniden inşa" şeklinde detaylandırılmadan basitçe "inşa" şeklinde belirtilmiş oluşudur. Oysa Panagia Kilisesi ilgisindeki 1883 tarihli işin, Moskhonisi başpiskoposu İzmirli II. Paisios (1872-1882) tarafindan başlatılıp ancak halefi Psaralı I. Iakovos (1882-1893) tarafından 
tamamlanabilmiş bir "yeniden inşa" olduğuna, ayrı bölümlerde açıklık getirilmiştir (Drakos, 1895b: $51,55)$.

Panagia'nın çanındaki yazıt, görünüşe bakılırsa kilisenin modern tarih yazımında oldukça kritik bir soruna neden olmuştur. Moskhonisili Sitsa Karaiskaki (1902-1987), Ali adlı bir Türk'ün adada yaşayanlarla beraber Panagia'nın inşasına mucizevi yardımına dair bir rivayetten bahsetmektedir (Karaiskaki, 1973: 79-80). Benzer şekilde Ali Onay'ın (1918-2016) da 1928'de kendisi 10 yaşındayken, yine bir başka Moskhonisili olan Spyros Tsakirakis adlı tüccardan aldığı sözlü bilgiye göre "Emin Ali Baltacı" adlı yerel bir demirci, 1860 civarında arka arkaya üç gün mucizevi bir rüya görmüss, akabinde yerel piskoposla görüşmüş, ve en son da Panagia'nın ana binasıyla çan kulesinin 1863 'te "boş bir alanda" inşasına önderlik etmiştir. Hatta kilisenin çanını da bizzat kendisi dökmüştür (Onay, 2000a: 37-40; 2000b; 2010).

Halbuki 1863 yılı Panagia'nın ne boş bir alana ilk inşası, ne de yeniden inşasıdır. Mimari kısıtlamaların kaldırılmasının ardından bu tarihte ilk çan kulesine ve Almanya'dan temin edilmiş bir de çana kavuşmuştur. Dönemin güvenilir birincil kaynaklarından Drakos $(1888,1895 \mathrm{a}, 1895 \mathrm{~b})$ da Panagia'nın 1860'lar için bir inşa ya da yeniden inşasından bahsetmez, ancak değinildiği üzere adadaki kiliselere 1865 dolaylarında çan kuleleri eklendiğini aktarır ki bu da çanın 1863 tarihli yazıtıyla tutarlıdır. Panagia için belirttiği bir yeniden inşa ise, alıntılandığı üzere 1883 tarihlidir. Yukarıda değinilen ikincil aktarımlar muhtemelen Panagia'nın 18. yüzyıl dolaylarındaki ilk inşasına istinaden 20. yüzyılın başlarında son halini almış bir şehir efsanesine dayanıyordu ki çok açık bir biçimde çanın üzerindeki "A $\Lambda$ H-AГA | E. A. MПA TTAZZH" (Ali-Ağa | E. A. Baltazzi) yazıt1 ve 1863 yıliyla harmanlanmıştır. Güncel olarak Psarros (2017: 322) da esasen Onay'ın (2000a: 37-40) şüpheli fakat popüler ikincil aktarımını ve Drakos'un (1888: 18-19, 1895a: 22-23) birincil tanıklığını en kısa halini, eleştirel bir yaklaşım veya arşiv araştırması olmaksızın basitçe harmanlayarak Panagia için çalışmaların 1863 'te başladığını, Osmanlı yetkilileri tarafından yavaşlatıldığı için 20 yıl sürdüğünü ve ancak 1883 'te tamamlandığını iddia etmektedir. Aşağıda tartışılan arşiv belgeleri ise tüm bu belirsizliklere yönelik çok daha detaylı bilgi sunmaktadır.

7 Ağustos 1882 tarihinde, Yunda'nın Rum sakinleri adına Osmanlı Adliye Nezâreti'ne bir dilekçe yazan Patrik III. Ioakeim (1878-1884, 1901-1912), Cezâyir-i Bahr-i Sefîd Vilâyeti'nin Midilli Adası'na bağlı Yunda Adası'ndaki Meryem Ana (Panagia) Kilisesi'nin zamanla harabeye döndüğünü ve ayin yapmak için uygunsuz hale geldiğini belirtmiştir. Böylece kilisenin 33 arşın uzunluğunda, 26 arşın genişliğinde ve 18 arşın yüksekliğinde $(1 \operatorname{arşın~}=757-758 \mathrm{~mm}) ; 34$ pencere ve 5 kapıyla; ve hiç kimseye zarar vermeden tekrardan inşa edilmek suretiyle yenilenmesi talep edilmiştir (BOA, İ.DH, 875-69842, H-20-03-1300).

Patrikhanenin resmi talebi üzerine Adliye Nezâreti, 24 Ağustos 1882'de vilayeti görevlendirmiş̧ir. Yunda'da Rumlardan başka bir cemaatin olmadığı, dolayısıyla kilise inşasından rahatsız olacak Müslüman nüfusun mevcut bulunmadığı belirtilse de adada demografik bir tahkikat yapılmasının, bürokratik prosedür nedeniyle gerekliliği vurgulanmıştır (BOA, İ.DH, 875-69842, H20-03-1300). Yunda'da yapılan 8 Kasım 1882 tarihli vilayet soruşturmasında, burada birçok kilise bulunsa da söz konusu kilisenin arsasında bir ayazmanın bulunduğu ve cemaatin de bunun şifa özelliğine inandığı bildirilmiştir ki kilisenin yeniden inşasına yönelik asıl gerekçe budur. Öyle ki, özellikle de kilisenin yortu gününde olmak üzere bu ayazmayı her gün 40-50 kişi düzenli olarak ziyaret etmektedir. Ayrica Yunda'da toplam 1297 konutta ikamet eden ve tamamı Hiristiyan 1933 erkek nüfusun bulunduğu ifade edilmiş, cemaati ise devlet otoritesine daima sadık, barış̧̧ıl ve saygılı olarak tanımlanmıştır. Kilisenin yeniden inşasına dair de belirtilenden başka bir niyetin olmadığ edilecek olsa da yapının eski taban alanı kısmen terk edilecek ve aynı arsanın içinde kalmak kaydıyla kilise eşdeğer düzeyde bir miktar kaydırılarak eski temelleri tamamen değiştirilecektir. Tahkikatın sonucuna göre, inşaat iznine karşı hiçbir yasal engel yoktur (BOA, İ.DH, 875-69842, H20-03-1300). 
8 Kasım 1882 tarihli vilayet soruşturmasına, yeniden inşa edilecek Panagia'nın bir kat planı ve ön cephe görünümü de eklenmiştir. Neoklasik üsluptaki kilise, basamaklarla ulaşılan kâgir bir platform üzerinde yükselen üç nefli ve beşik çatılı bir bazilikadır. Apsis ve yan apsisleri tam yarım daire formunda dişa taşmaktadır. İyon düzeninde sütunlara sahip iki katlı bir narteks ile üç cephesi tamamen çevrelenmiştir. Yedi pencereli ön cephesine anıtsal bir görünüm veren üçgen alınlığın ortasında, yarım daire biçimli bir aydınlık penceresi bulunmaktadır. Patrik III. Ioakeim'in 7 Ağustos 1882 tarihli dilekçesinde Osmanlı arşınıyla belirtilen boyutları, bu kez Yunan arşınına göre yaklaşı eşdeğerleriyle 30 pikhi uzunluk, 25 pikhi genişlik ve 13 pikhi yükseklik şeklinde verilmiştir. Tüm bu değerler de ortalama olarak 25 metre uzunluk 20 metre genişlik ve 14 metre yüksekliğe tekabül etmektedir (pikhi $=$ arşın) (Şek. 4). Dahas1, vilayet soruşturmasındaki bir ifadeden, I. Kallinikos tarafindan 1832-1834 dolaylarında yeniden inşa edilerek 1883'e kadar mevcut bulunmuş Panagia kilise binasının da yine aynı plan tipine ve ölçülere sahip olduğu anlaşılmaktadır. Bu bağlamda bire bir aynı kilise binası, yalnızca arsası içerisinde bir miktar kaydırılmak suretiyle yeni temeller üzerinde tekrardan inşa edilecektir.

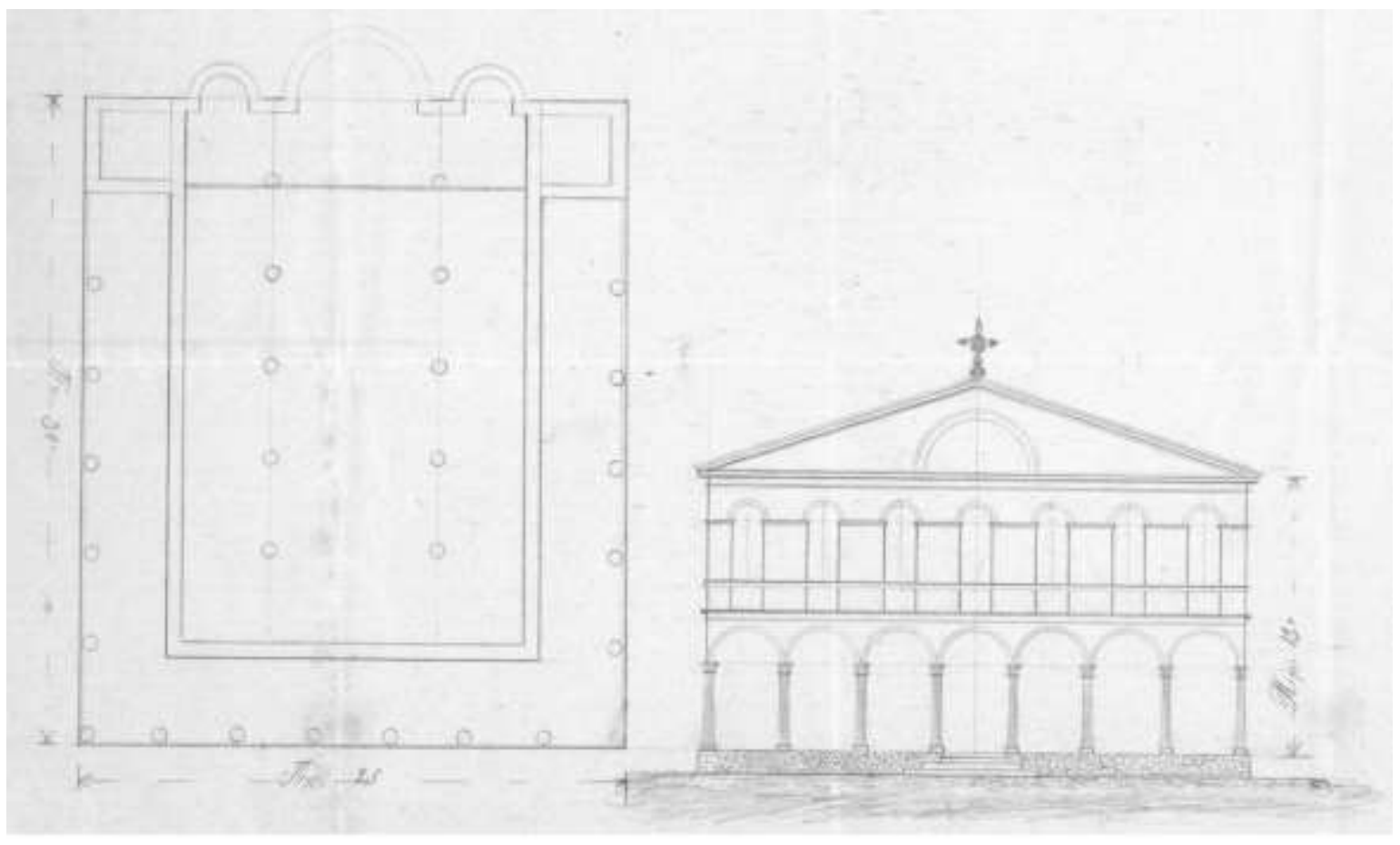

Şekil 4: Panagia Kilisesi'nin yeniden inşasına yönelik 1882 tarihli plan (BOA, İ.DH, 875-69842, $\mathrm{H}-20-03-1300)$.

Panagia'nın yeniden inşasına yönelik patrikhane talebi, bu kez Dîvân-1 Hümâyun tarafından 13 Aralık 1882 tarihinde onaylanmış, aynı esnada adada yapılmış tahkikat ve yeni yapının mimari özellikleri bir kez daha özetlenmiştir. Ayrıca eski kilisenin en baştan beri yalnızca Yunda Rum cemaatine ait olduğu ve inşa edilecek yeni kilisenin temellerine yönelik bir miktar kaydırma işleminin de yine kilisenin orijinal arsasının sınırları içerisinde yapılacağı teyit edilmiştir. Tüm bu prosedür Adliye Nezâreti tarafindan 21 Aralık 1882'de, sadrazam tarafindan da 27 Ocak 1883'te onaylamıştır. Nihayet Yunda'daki yıkık Panagia Kilisesi'nin yeni temeller üzerinde tekrardan inşası için gerekli izin, padişah tarafindan 29 Ocak 1883 'te verilmiştir (BOA, İ.DH, 875-69842, H-20-031300) (Şek. 5). 


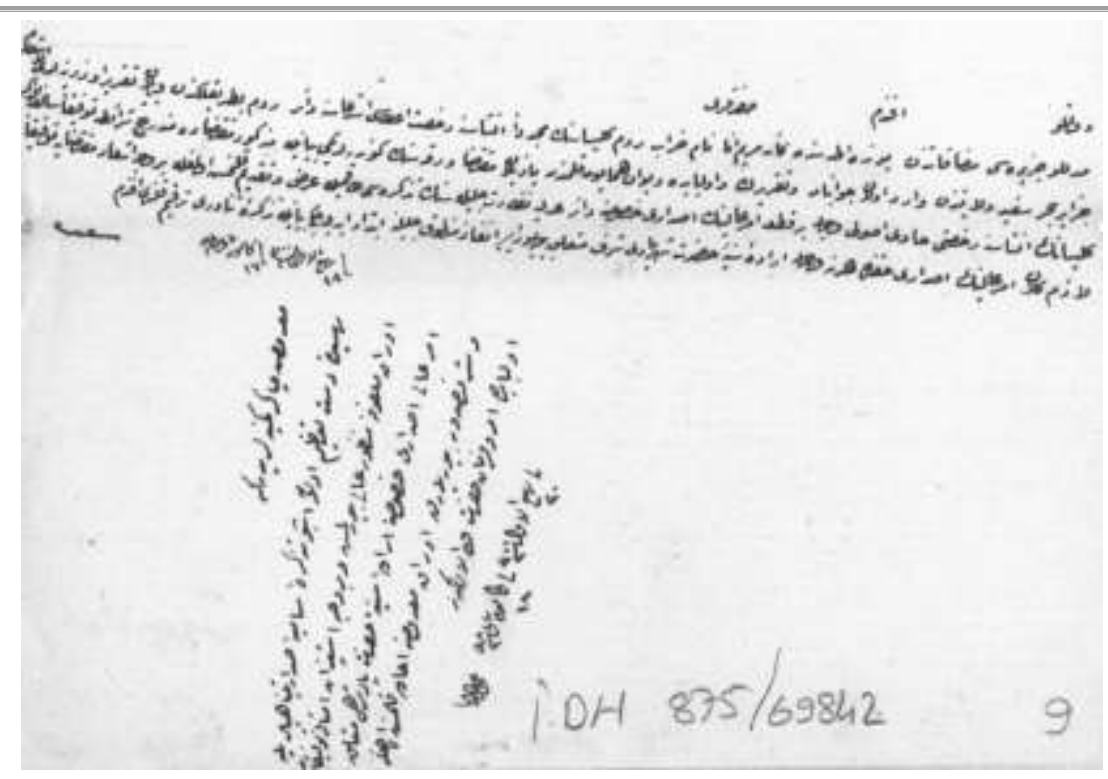

Şekil 5: Panagia Kilisesi'nin Ocak 1883 tarihli yeniden inşa izni (BOA, İ.DH, 875-69842, H-20-031300).

Osmanlı döneminde, İslami geleneğe dayalı ve Islahat Fermanı'na (1856) kadar sürecek genel bir uygulama olarak yeni kilise ve sinagogların inşasına değil, ancak mevcut olanların yeniden inşasına izin verilmekteydi. Buna karşın özellikle de ağırlıklı olarak gayrimüslimlerin yaşadığı yerleşimlerde, bu hususta pek çok istisnai durum yaşanmaktaydı (Demirel, 2005: 212-217; Koyuncu, 2014: 53-55). Midilli Sancağı'ndaki hızlı ekonomik büyüme sonucu 1881-1912 arasında, Yunda Panagia Kilisesi'nin de dahil olduğu en az 14 Rum Ortodoks kilisesi sancak genelinde inşa edilmiş veya yeniden inşa edilmiştir (Ünver, 2012: 254-255). Bu tür çalışmalar, artış gösteren nüfusun ibadethane ihtiyacını karşılamanın yanında bölgede arka arkaya gerçekleşmiş depremlerle de ilgili olabilir, zira 1845-1893 yılları arasında Midilli ve yakın çevresini etkilemiş 29 önemli deprem kaydedilmiştir (Soysal vd., 1981). Bunu Panagia ilgisinde doğrularcasına, Patrik III. Ioakeim'in 7 Ağustos 1882 tarihli dilekçesinde de kilisenin zamanla harabeye döndüğü belirtilmişti (BOA, İ.DH, 875-69842, H-20-03-1300).

İsyan kaynaklı 1821 tahribatı nedeniyle Panagia Kilisesi'ni 1834 dolaylarında yeniden inşa ettirmiş olan Moskhonisili I. Kallinikos, 1832-1842 arasındaki başpiskoposluk görevi sonrasında Athos Dağı'na çekilerek münzevi bir yaşam sürmüştür. Yine de memleketine ve Panagia'ya yönelik ilgisini sürdürmüş, 1888 'de değerli ayin kıyafetleri ve ayin eşyaları göndererek kiliseyi süslemiştir ki burayı 1883 'te yeniden inşa ettirmiş bir diğer başpiskopos olan Psaralı I. Iakovos'un 26 Eylül 1888 tarihli bir teşekkür mektubunda bahsedilmektedir (Drakos, 1895b: 29-30) (Şek. 6-7). 


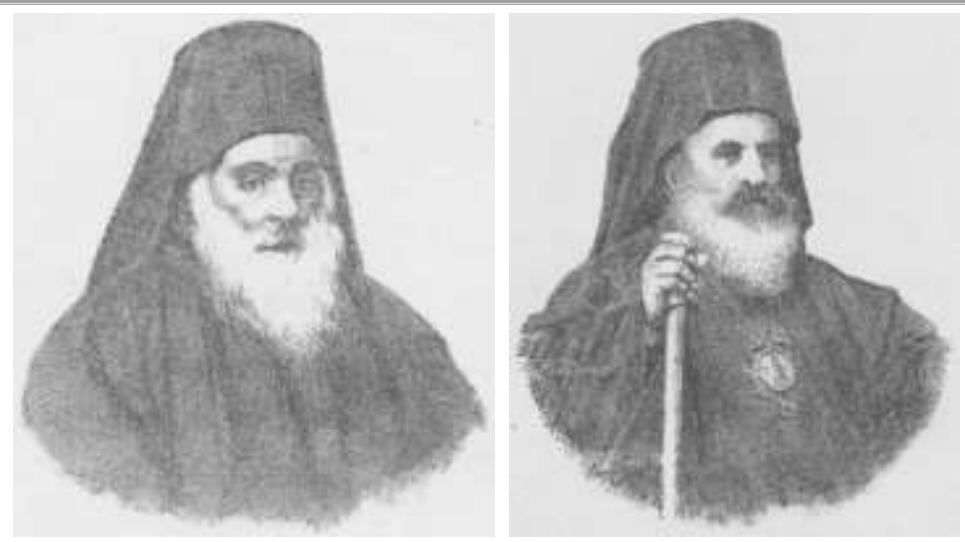

Şekil 6-7: Panagia Kilisesi'ni farklı zamanlarda yeniden inşa ettirmiş başpiskoposlardan I. Kallinikos (1832-1842) ve I. Iakovos (1882-1893) (Drakos, 1895a).

Katedral kilisesi 1873 'ten itibaren Taksiarkhis olsa da Panagia'nın adadaki idari ve ekonomik nüfuzunu sürdürdügü anlaşılmaktadır. Öyle olmalı ki, 1890'ların ortaları itibariyle Moskhonisi'de yirmi yıldan beridir yerel dolaşımda olan ve yaklaşık 60.000 kuruş tutarındaki yasadışı banknotların üzerine Panagia Kilisesi'nin sembolü basılmıştı (Drakos, 1895b: 13). Osmanlı hükumeti 26 Eylül 1894'te harekete geçerek bu banknotları toplatmış ve imha ettirmiştir (BOA, DH.MKT, 287-38, H-25-03-1312; Drakos, 1895b: 59). Dahası, Moskhonisi'nin 1909-1912 arası üç yıllık kilise idaresi denetim komitesi raporuna göre Panagia, 30.000 kuruş civarındaki yıllık geliriyle yerleşimin açık ara en zengin kilisesiydi. Bu sayı, adadaki diğer bütün kiliselerin toplam y1llık gelirini dahi geçmekteydi ve ikinci sırada bulunan dönemin katedral kilisesi Taksiarkhis'inkinin de yaklaşık 4,5 katıydı (Chatzapostolis vd., 1913: 7). Panagia'nın tüm bu zenginliği muhtemeldir ki arsasında bulunan ve şifa bulma amacı taşıyan birçok kişinin düzenli olarak ziyaret ettiği ayazmayla ilgiliydi. Buradaki fazlalık suların, ada sakinlerinin kullanımı için 1876'da yerleşim merkezine verilmesine başlandığı üzere (Drakos, 1895b: 46), Panagia Kilisesi'nin kent altyapısı için de çok önemli bir kompleks olduğu anlaşılmaktadır. Öyle ki, adadaki suyun azlığından dolayı Yunda ahalisi çokça sıkıntı çekmekte olup "Krinilaki" (Çeşmecik) adlı çeşme ile Pera Mosko'dan (Pınar Adası) çıkan sular yetersiz kalmaktaydı (Cezâyir-i Bahr-i Sefîd Vilâyeti, 1893: 292; 1898: 272; 1903: 265) (Şek. 8-9).

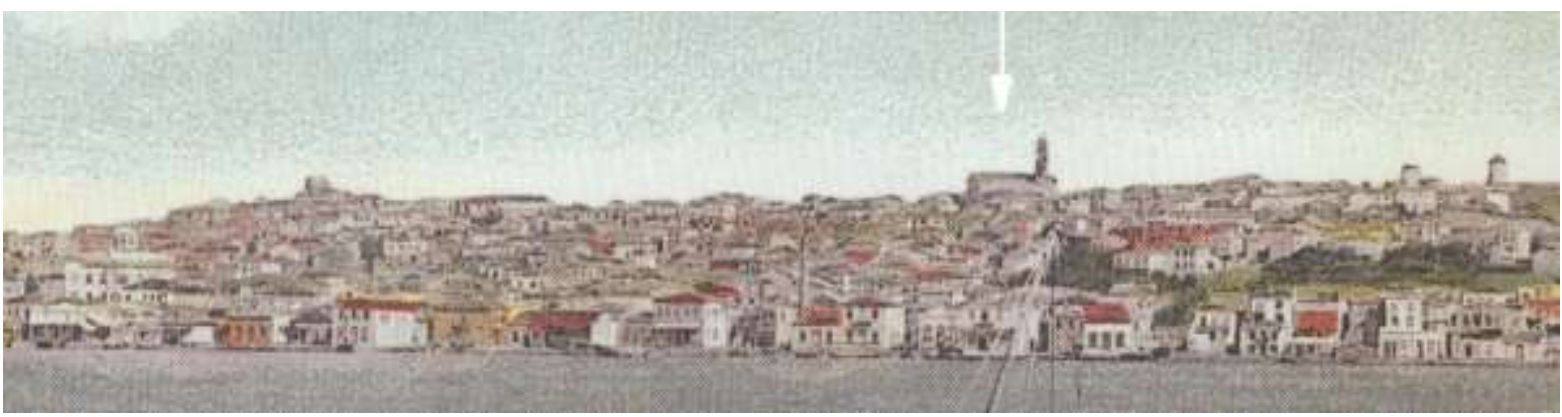

Şekil 8: 1906 tarihli bir Ioannis Kontaksis (namı diğer Jean D. Contaxis) panoramasında, yüksek yapısıyla öne çıkan Panagia Kilisesi (Série IV - Ville de Mosconissi) (Deniz Eren Kişisel Arşivi). 


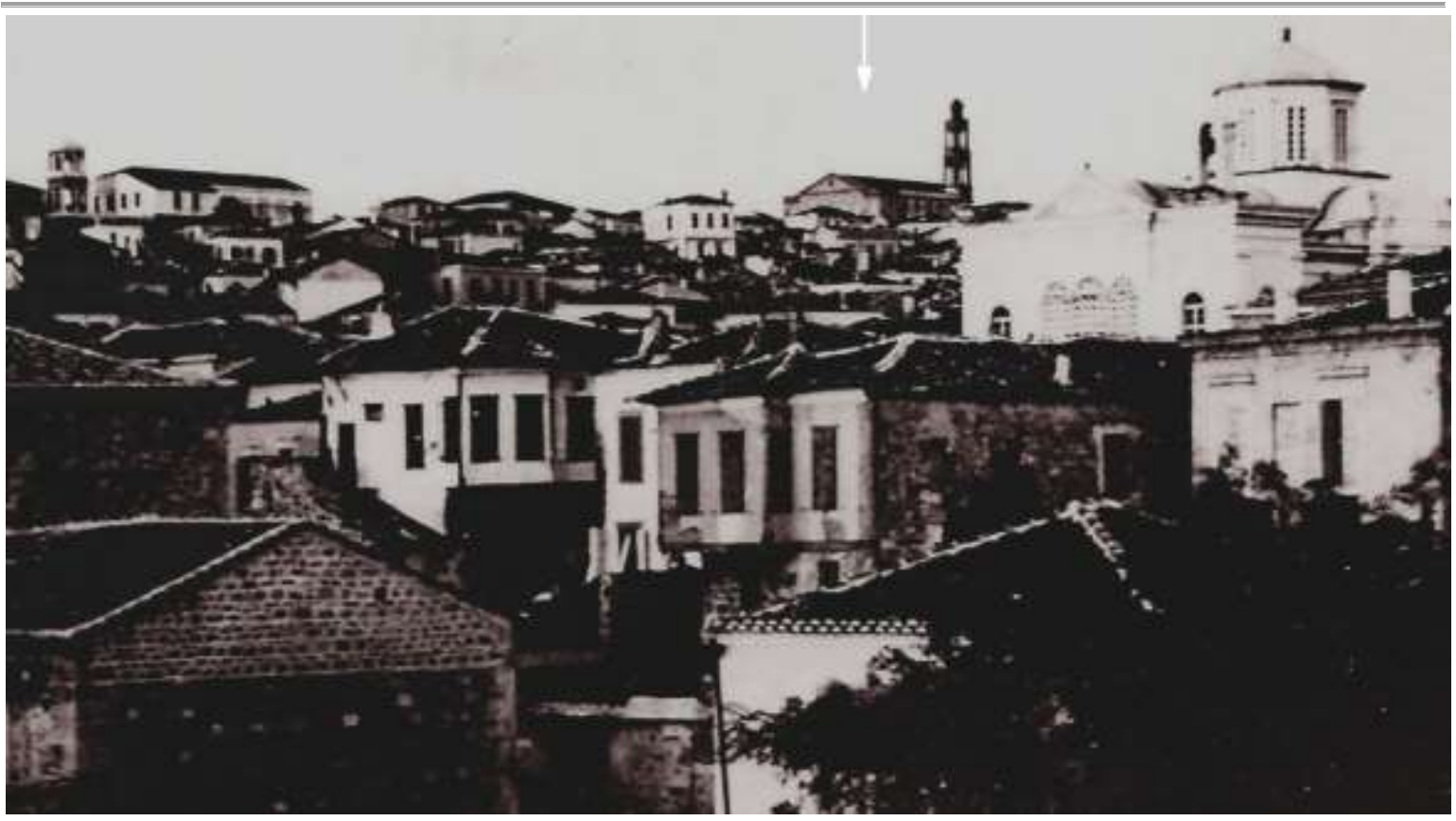

Şekil 9: 1906 tarihli bir fotoğrafta, en geride Panagia Kilisesi (Dr. Maria Tsitimaki'nin izniyle)

(ChAE, Georgios Lampakis Koleksiyonu, 6027).

Karaiskaki (1973) ve Onay'in (2000a) tanıklıkları, Psarros (2017: 321-327) tarafindan kabataslak bir vaziyet planı eşliğinde alıntılanmıştır. Buna göre 1883 tarihli bina, karakteristik pembemsi bir renge sahip "Sarımsak" adlı yerel taştan kesme bloklarla inşa edilmişti. Üç nefli bazilika, adanın en büyük kilisesiydi. Ahşaptan basit bir beşik çatıya sahip olup ana nefi yükseltilmemişti. Dikdörtgen biçimli büyük kompleksin tüm kuzey kanadı boyunca uzanan iki katlı bir yönetim ve misafirhane binası vardı. Kilisenin arkasında tuvaletler; demir parmaklıklı yüksek duvarların çevrelediği avluda da büyük bir şapel bulunmaktaydı. Renkli çakıl taşlarından dekoratif desenlere bezeli avlu üç girişliydi. Bunlar da batı ve güneybatıya doğru açılmaktaydı. Merkezdeki kilisenin içi zengin mimari unsurlara ve fresklere sahipti. Sıvalı ahşaptan tavanında bir kubbe ve yarım kubbeler bulunmaktaydı. Zemini ise siyah ve beyaz mermer levhalarla döşenmişti. Büyük çan kulesi ise güneydeydi (Karaiskaki, 1973; Onay, 2000a; Psarros, 2017: 321-327).

Psarros'un (2017: 322) vaziyet planı krokisinde Panagia sembolik olarak tipik üç nefli ve ahşap çatılı bir bazilika şeklinde tasvir edilmiş olup iki katlı narteksi yan cepheleri yarı hizaya kadar örtmektedir. Güneyindeki çan kulesi ise müstakil bir vaziyettedir. 19. yüzyılın ortasındaki Tanzimat ve Islahat fermanlarına kadar sürmüş mimari kısıtlamalar nedeniyle Osmanlı Devleti bünyesindeki Hıristiyanlar, bazilika plan tipindeki kiliseleri sıkça tercih etmişti (Karaca, 2008). Yan cepheleri kısmen örten U biçimli taşkın bir nartekse ve sıra pencerelerle yükseltilmiş bir orta nef nedeniyle fenerli çatıya sahip bazilika tipolojisi, Osmanlı'nın son dönemleri itibariyle Kuzey Ege'de ve bilhassa Ayvalık yöresinde oldukça yaygındı (Tsitimaki, 2007). Halbuki 8 Kasım 1882 tarihli rekonstrüksiyon planına ve eski fotoğraflara göre Panagia bu tipte bir bazilika değildi. Narteks birimi, yan cepheleri tamamen örtmekteydi ve kilisenin üzerinde yalın bir beşik çatı vardı. Dahası, çan kulesi bağımsız yapıda değildi ve kilise binasının bir parçasıydı.

Panagia'nın 1863'ten bu yana bir çan kulesi olsa da ne 1882-1883 tarihli resmi belgelerde, ne de rekonstrüksiyon planında bu açıkça belirtilmiştir. Buna karşın narteksin yan apsislere bitiştiği köşelere kare biçimli kâgir birimler eklenmiştir ki yeni çan kulesi de bunlardan güneydekinin doğrudan üzerinde yükselmekteydi. Drakos (1888: 18-19) da çan kulesinin varlığını en erken 1888 itibariyle teyit etmektedir. Görüldüğü kadarıyla Panagia'ya ilk çan kulesi 1863 'te eklenmiş̧ olsa da 8 
Kasım 1882 tarihli vilayet soruşturmasındaki rekonstrüksiyon planında kilise, bu kez doğrudan entegre çan kuleli biçimde tasarlanmıştır. Dolayısıyla tahkikatta her ne kadar Panagia'nın 1883'te yeniden inşa edilecek binasının, çan kulesi sonradan eklenmiş 1832-1834 tarihli bir önceki yapıyla aynı olacağı ifade edilmiş olsa da bu çan kulesi özelinde bahsi geçmemiş önemli bir farklılık söz konusudur. Yine de 1863 tarihli eski çanın, yeni kulede tekrardan kullanıldığ 1 anlaşılmaktadır. Ayrıca 1906 tarihli bir fotoğrafında (Şek. 9) ön cephede, alınlık hizasından ve yan cephelerden taşan, düz tavanlı birimlerin olduğu görülmektedir. Bu düzenleme de planla uyuşmamaktadır.

Midilli'deki bazı vakalar, 17-19. yüzyıllarda Rumların kiliselerin onarımı veya yeniden inşası esnasında yerel yetkililerle işbirliği yaparak imar kanunlarına defalarca aykırı hareket ettiklerini göstermektedir (Tsitimaki \& Shariat-Panahi, 2014). Daha yakın bir örnek olarak, 18911894 tarihli iki arşiv kaydına göre kaymakam Ioannakis'in görevini suistimali neticesinde Yunda Adası'nın güneydoğusundaki Dolap mevkiinde bir kilise, herhangi bir izin olmadan tamamen kaçak şekilde inşa edilmiştir (BOA, DH.MKT, 308-75, H-16-05-1312; ŞD, 2351-31, H-29-06-1312). 1883 'te yeniden inşa edilen Panagia'da söz konusu mimari tutarsızlıklar da bu hadiselerle izah edilebilir. 1923 sonrası atıl hale düşen Panagia'nın narteks sütunları sökülerek 1927'de Edremit'e götürülmüsştür. 1944 depreminde ağır hasar gören yapı 1954 yılında yıktırılmış ve taşları da Nuri Zarplı İlköğretim Okulu'nun inşasında kullanılmıştır (Onay, 2000a: 46-47) (Şek. 10-11).

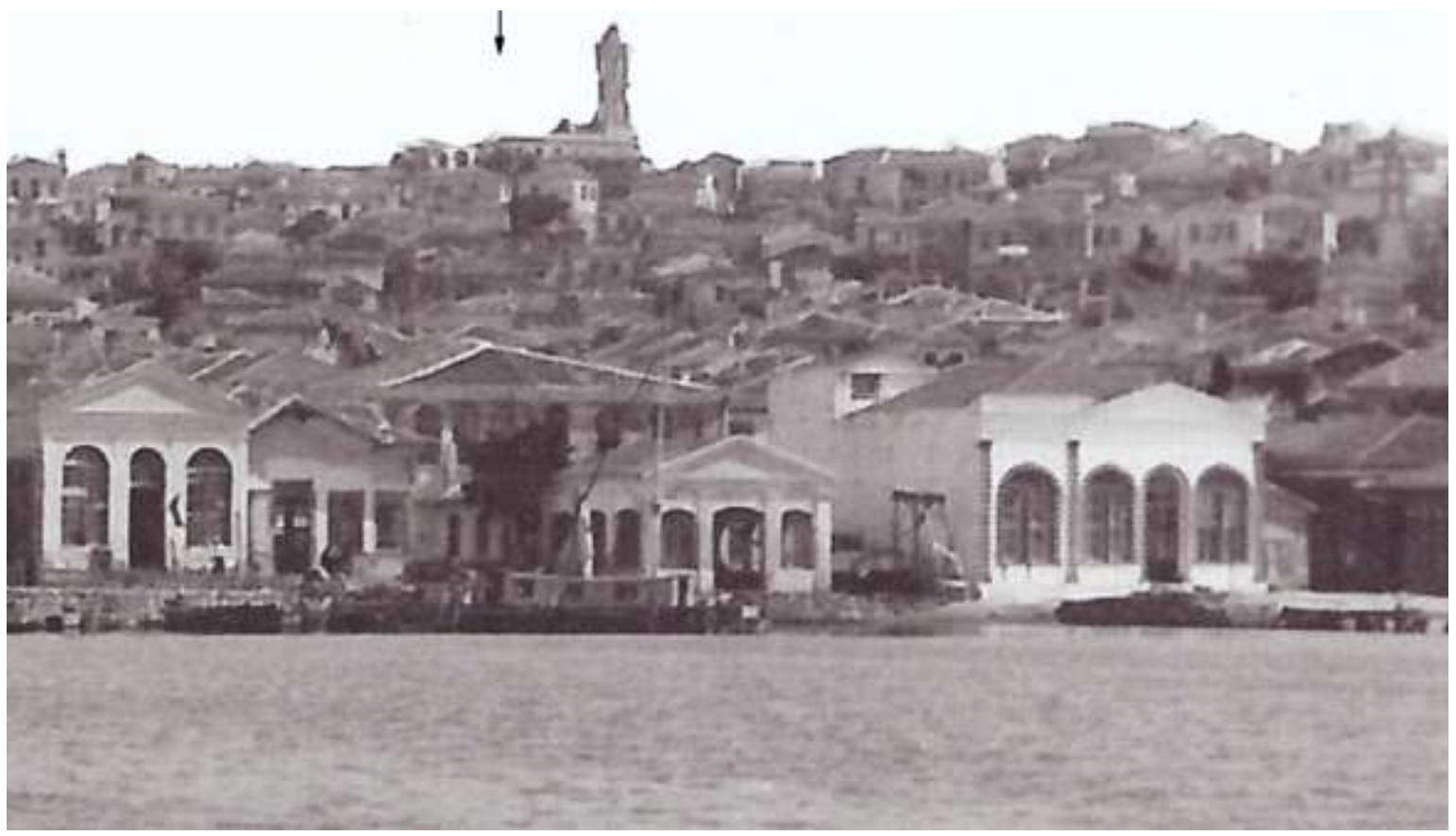

Şekil 10: 1940'larda Panagia Kilisesi'nin uzaktan görünümü (Kaptan vd., 2019). 


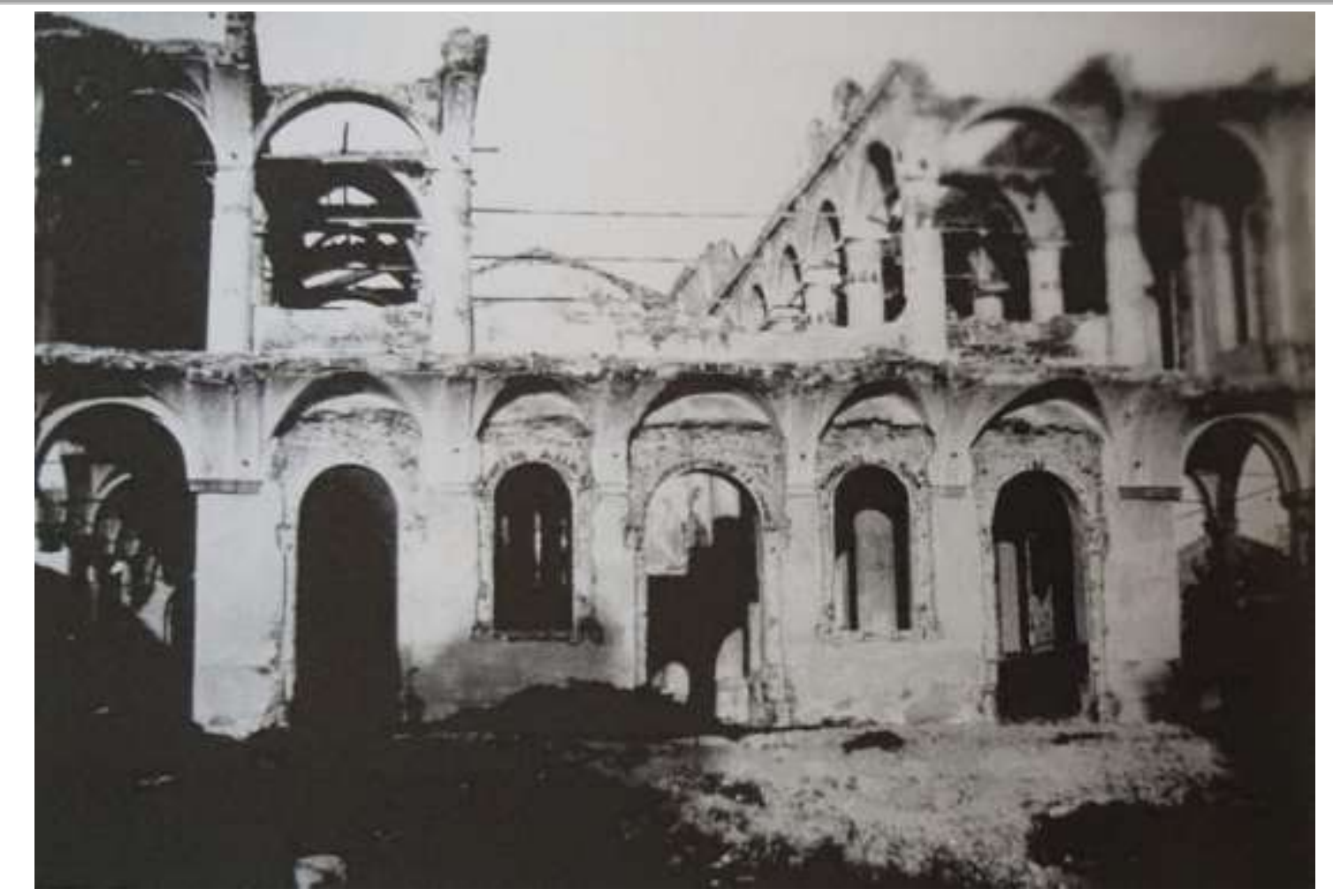

Şekil 11: 1940 yılında Panagia Kilisesi'nin harap haldeki ön cephesi (Kaptan vd., 2019).

Günümüzde Panagia'nın arsası zemin seviyesinden yaklaşı 3 ila 5 metre yükseklikteki büyük bir enkaz yığınıyla tamamen kaplıdır. Yıkık yapılara ait karışık malzemeden harap bölümler bir dereceye kadar her yerde görülebilmektedir. Avlunun güneybatı köşe girişi en belirgin kısımdır. Kısmen korunmuş avlu duvarları kabaca yontulmuş dikdörtgen blokların, üst üste yassı küçük parçalardan oluşan dikey bölümlerle ayrıldığ tekniğine sahiptir. Bu teknik 19-20. yüzyıl yapılarında bir hayli yaygındır (Şek. 12-13-14).

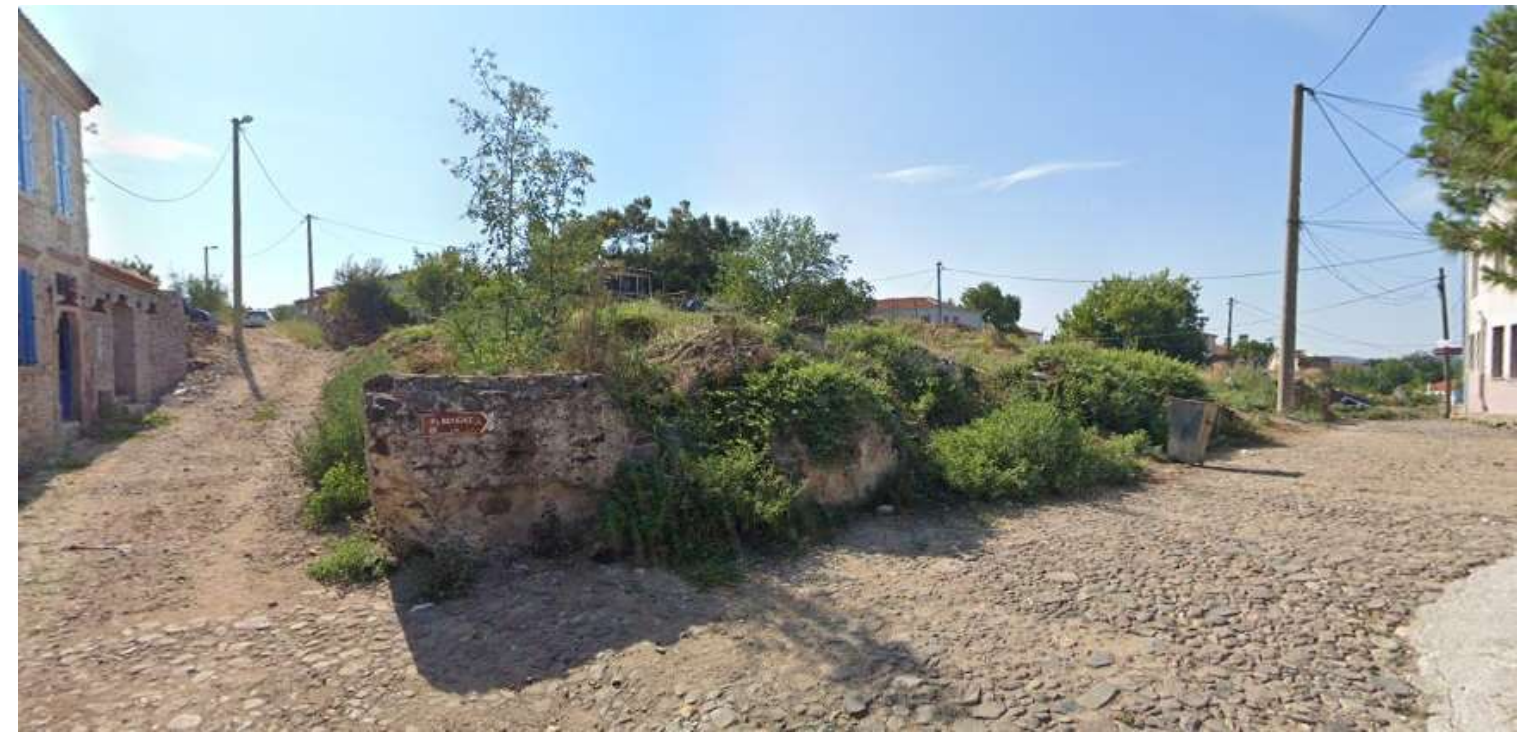

Şekil 12: Panagia Kilisesi'nin arsasının kuzeybatıdan görünümü (KEAM, 2020). 


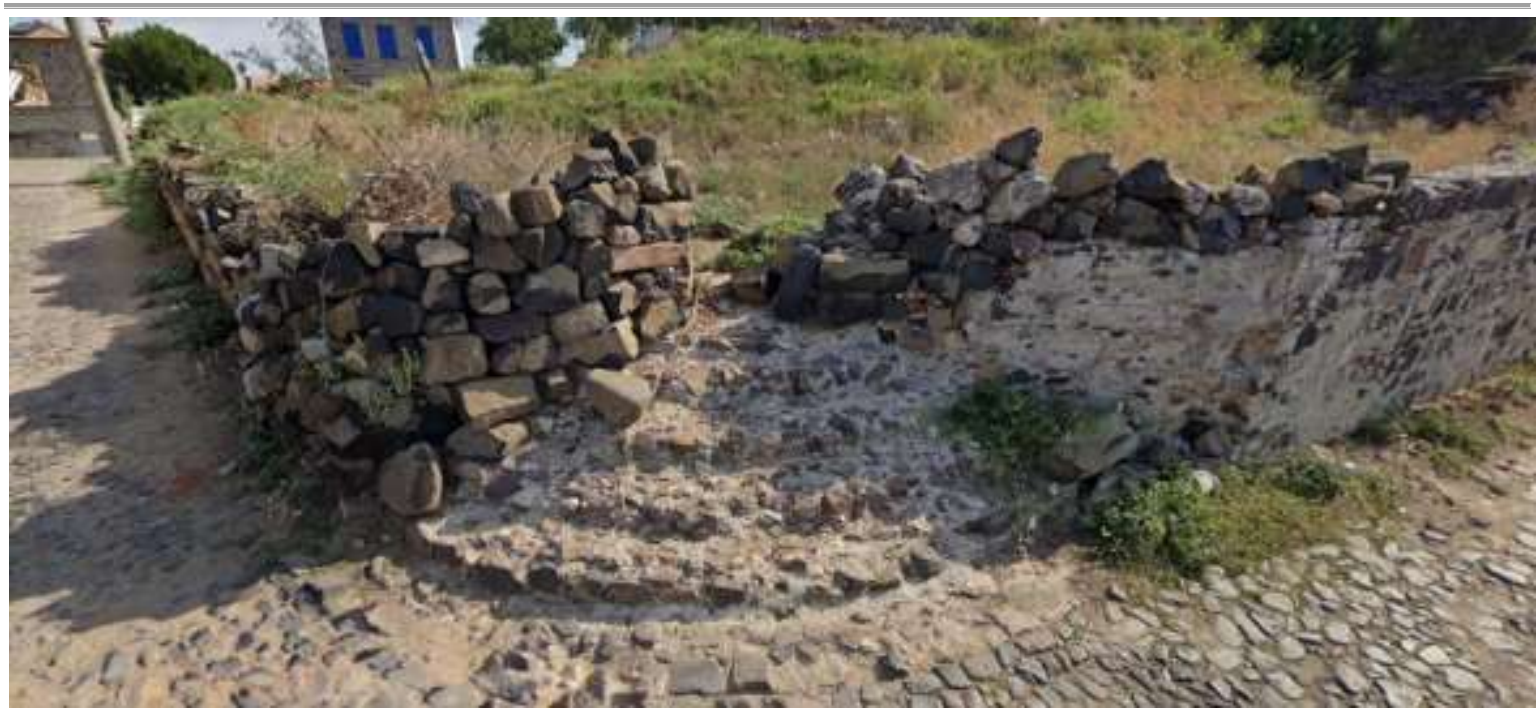

Şekil 13: Panagia Kilisesi'nin arsasının güneybatıdan görünümü (KEAM, 2020).

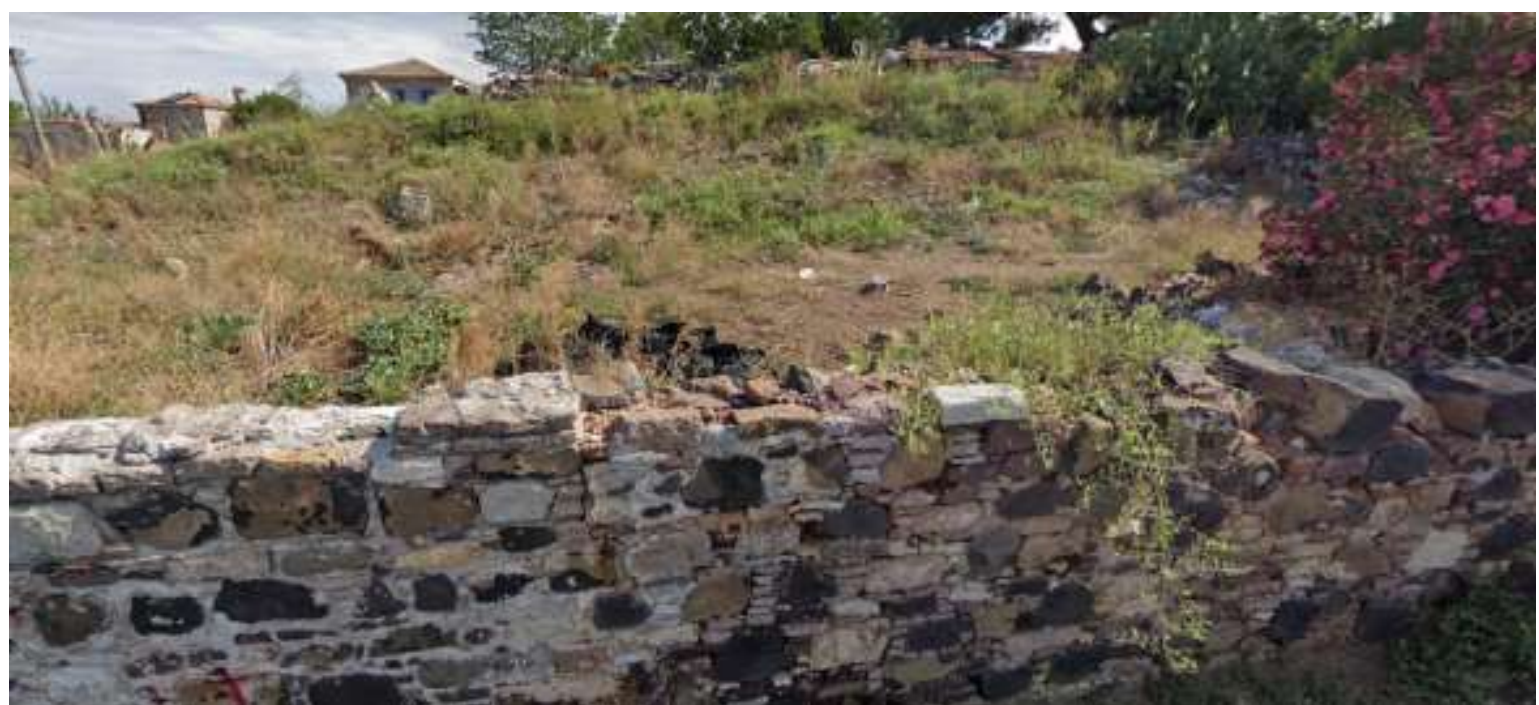

Şekil 14: Panagia Kilisesi'nin arsasının güneyden görünümü (KEAM, 2020).

\section{Agios Panteleimon Kilisesi}

Panagia'ya benzer şekilde Agios Panteleimon'un da ilk ne zaman inşa edildiği bilinmemektedir. En eski kayıt, Moskhonisi'deki bazı idari işlere dair 14 Ağustos 1841 tarihli bir belgede, şehrin ileri gelenlerinden birisinin Agios Panteleimon Kilisesi'ne ait bir kutsal emaneti zimmetine geçirmesiyle ilgilidir (Drakos, 1895b: 26). Daha sonra Drakos (1888: 19; 1895a: 22-23), Agios Panteleimon Kilisesi'nin 1882'de "inşa edildiğini" ifade etmektedir ki bu iş, dönemin Moskhonisi başpiskoposu İzmirli II. Paisios öncülüğünde bir yeniden inşadır. Daha sonra da 18941895 itibariyle, gelecekteki Agios Panteleimon Kilisesi için yirmi yıldır para toplandığını aktarmaktadır (Drakos, 1895b: 61). Aşağıda tartış1lan belgeler, bahis konusu ikinci yeniden inşa hakkında ayrıntılı bilgi sağlamaktadır.

14 Haziran 1895 tarihinde Patrik VII. Anthimos (1895-1897), Adliye Nezâreti'ne bir dilekçe yazarak Cezâyir-i Bahr-i Sefîd Vilâyeti'nin Yunda Adası'ndaki Agios Panteleimon Kilisesi'nin zamanla harap olduğunu ifade etmiş, bu yüzden de yaklaşık 40.000 kuruş masrafla 25 
arşın uzunluğunda, 14 arşın genişliğinde ve 10 arşın yüksekliğinde olacak şekilde yeniden inşasına izin talep etmiştir (BOA, ŞD, 2661-55, H-28-05-1313). Bakanlık 9 Temmuz 1895 tarihinde, söz konusu yeniden inşa talebiyle ilgili vilayetten bir soruşturma talebinde bulunmuştur. Buna yönelik 29 Ağustos 1895 tarihli raporda ise kilisenin, eski temellerinin üzerine inşa edilmeyeceği, ancak yine kendi arsası içerisinde kalmak koşuluyla caddeden 8 metre içe çekileceği bildirilmiştir. Yeni bina 19 metre uzunluğunda, 11 metre genişliğinde ve 7,5 metre yüksekliğinde, kâgir bir yap1 olacaktır. İhtiyaç duyulan yaklaşık 40.000 kuruşluk masraflar da 30-40 yıl boyunca toplanmış mum bağışlarından karşılanacaktır. En sonda da bahis konusu yeniden inşaya yönelik hiçbir kanuni engelin olmadığ 1 belirtilmiştir. Bu tahkikat raporu, vilayet genel meclisince onaylanarak 30 Eylül 1895 tarihinde bakanlığa sunulmuştur (BOA, ŞD, 2661-55, H-28-05-1313).

Bakanlık ve ardından Dîvân-1 Hümâyun, yeniden inşaya yönelik prosedürü Ekim 1895 'te onaylamışıı (BOA, ŞD, 2661-55, H-28-05-1313). 16 Kasım 1895 tarihli Şûrâ-yı Devlet onayı, iki adet ayrıntılı mimari planı da içermektedir (BOA, İ.AZN, 21-25, H-28-03-1314) (Şek. 15-16). Nihayet 29 Ağustos 1896'da sadrazam, 6 Eylül 1896 tarihinde ise padişah tarafindan Agios Panteleimon Kilisesi'nin yeniden inşası onaylanarak gerekli ruhsat verilmiş ve bu hususta Adliye Nezâreti de bilgilendirilmiştir (BOA, BEO, 841-63071, H-13-04-1314; I.AZN, 21-25, H-28-031314).

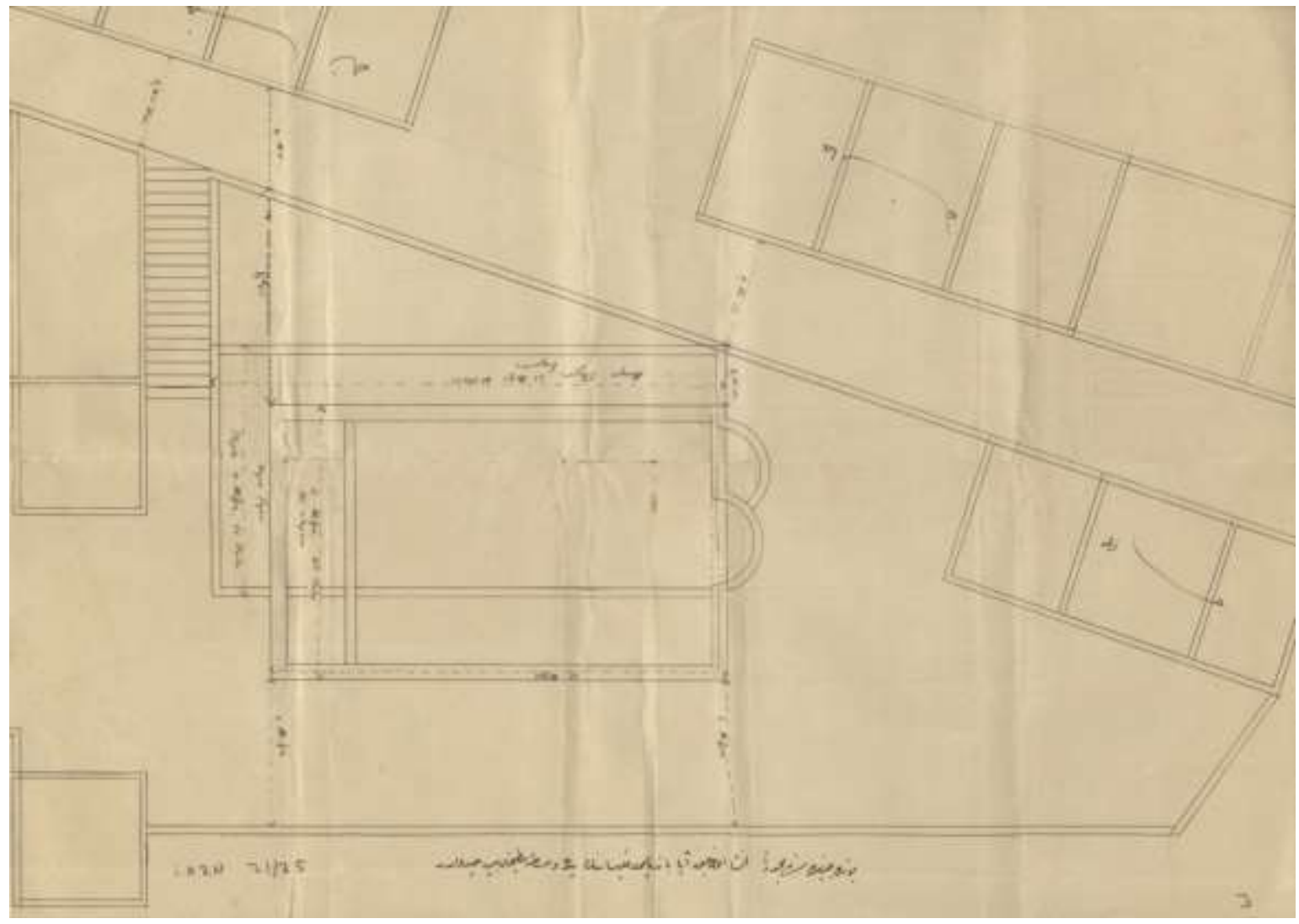

Şekil 15: Zamanla harap olmuş Agios Panteleimon Kilisesi'nin yeniden inşasına yönelik 1895 tarihli vaziyet planı (kuzeydoğu köşesi yola bitişik eski kilise binası ve buradan 2,50 metre güneye kaydırılarak inşa edilecek yeni kilise binası bir arada gösterilmiştir) (BOA, İ.AZN, 21-25, H-28-031314). 


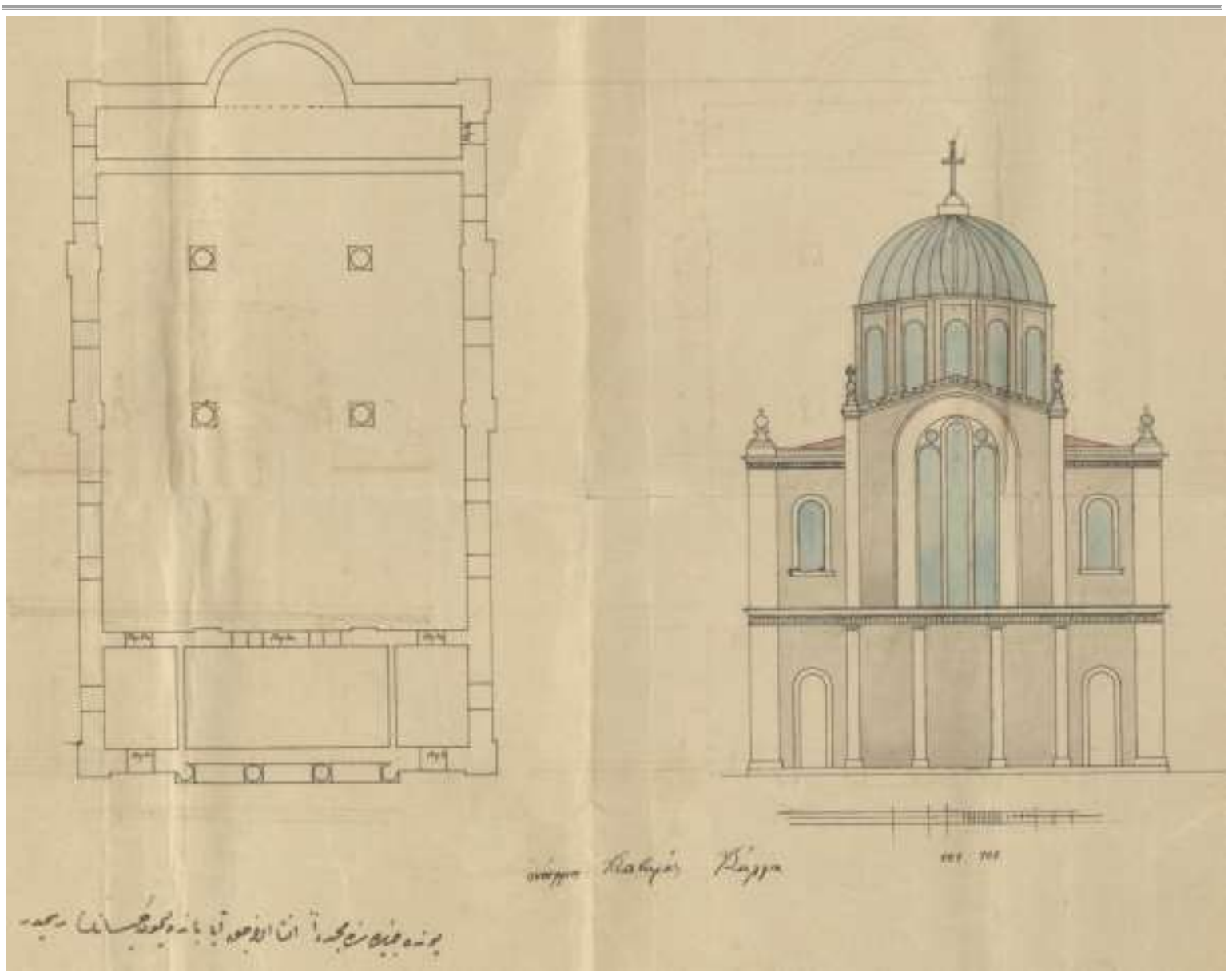

Şekil 16: Agios Panteleimon Kilisesi'nin yeniden inşasına yönelik 1895 tarihli kat planı ve ön cephe görünüşü (BOA, İ.AZN, 21-25, H-28-03-1314).

Kalfa Onoufrios Kouvaras imzalı yeniden inşa planı, dıştan yarım daire formlu tek apsisli eski kilisenin 21,40 metre uzunluğunda ve 10,50 metre genişliğindeki basit bir bazilika olduğunu göstermektedir. Yapının kuzeydoğu köşesi, arsanın kuzeyi boyunca uzanan caddeye bitişiktir. Daha kısa olan yeni kilisenin boyutları ise 19 metre uzunluk ve 11,40 metre genişlik şeklinde, Patrik VII. Anthimos'un 14 Haziran 1895 tarihli dilekçesindeki arşın değerleriyle uyumludur. Güneye doğru kaydırılmış yeni kilisenin kuzeydoğu köşesi, söz konusu caddeye 2,50 metre uzaklıktadır. Kuzeybatı köşe ise 8,60 metre uzaklıktadır. Oldukça dik bir alandaki avlu, her iki kilise yapısının da narteksine kuzeyden erişen 20 basamaklı bir girişe sahiptir. Batıdaki sokaktan muhtemelen bir diğer avlu girişi daha vardır. Arsanın güney kanadı, yeni kiliseden 6 metre uzakta kalacak bir istinat duvarıyla sınırlıdır. Uzunlamasına üçgen biçimli avluda biri doğuda, ikisi de batıda olmak üzere en az üç müştemilat vardır. Kilisenin kuzeyinde ve ortalama 4,20 metre genişliğindeki caddenin karşı tarafında, bitişik nizam konutlar sıralanmaktadır (BOA, İ.AZN, 21-25, H-28-031314).

1896 tarihli yeni kilise binası, kapalı Yunan haçı planlı ve neoklasik üsluptaydı. Üç birimli narteksin dört sütunlu bir portikosu bulunmaktaydı. Burası ile naos bölümü, birbirine üç adet giriş yoluyla bağlanmıştı. Güney cephenin doğu ucundaki küçük bir giriş doğrudan bemaya açılmaktaydı. Naosun ortasında bulunan kurşun kaplı kubbe, bir dizi dikey pencereyle yükseltilmiş olup altta naosu da bölen dört sütun tarafindan taşınmaktaydı. Kalan bölümler görünüşte tonozlarla örtülü olup üzerleri kiremitle kaplıydı. Yeni kilisenin tek apsisi dıştan yarım daire biçimliydi. Dışta 
iki katlı olan cephelere düzenli aralıklarla payandalar ve kemerli pencereler yerleştirilmişti. Hafifçe çıkma yapan portikonun üstünde, ortasında dikey bir üçlü pencere grubu bulunan yarım daire kemerli ve büyükçe bir açıklık, ana girişi süslüyordu. Alınlık hizası ise yandaki bölümlerden daha yüksekteydi (BOA, İ.AZN, 21-25, H-28-03-1314).

1909 itibariyle Georgios Lampakis, Agios Panteleimon'un ikonostasisinin esasen 1857'de, İzmir'deki Agios Georgios Kilisesi'nden çıkartılmış bir 18. yüzy1l eseri olduğunu belirtmektedir. Agios Panteleimon'u 1882'de yeniden inşa ettirmiş dönemin başpiskoposu İzmirli II. Paisios tarafından buraya getirtilmiştir (Lampakis, 1995). Durum böyleyse, 1893'te göreve gelmiş ve 1896'da Agios Panteleimon'u yeniden inşa ettirdiği anlaşılan daha sonraki başpiskopos Çeşmeli I. Theoklitos, II. Paisios tarafindan 1882 'de getirtilmiş eski ikonostasisi korumuştur (Şek. 17-18). Moskhonisi'nin 1909-1912 arası üç yıllık kilise idaresi denetim komitesi raporuna göre Agios Panteleimon Kilisesi, yaklaşık 2500 kuruşluk yıllık geliriyle beş ana mahalle arasında en son sıradaydı (Chatzapostolis vd., 1913: 7). Buradan hareketle kuvvetle muhtemeldir ki adadaki yerleşim merkezinin en az nüfusa sahip mahallesini temsil etmekteydi.
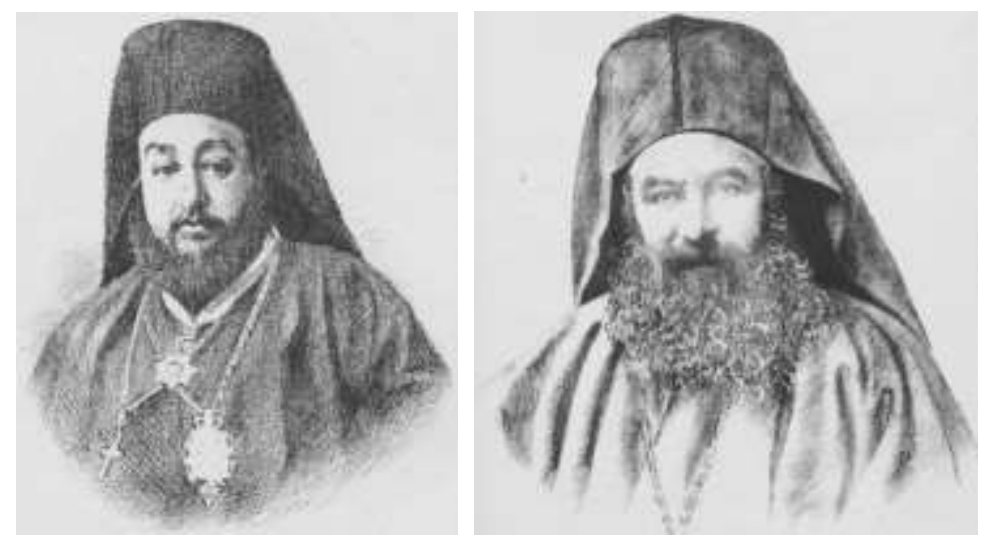

Şekil 17-18: Agios Panteleimon'u farklı zamanlarda yeniden inşa ettirmiş başpiskoposlardan II. Paisios (1872-1882) ve I. Theoklitos (1893-?) (Drakos, 1895a).

Henüz doğrulanamamış bir ikincil aktarıma göre Agios Panteleimon, 1915'te bir kez daha inşa edilmiştir ve duvarları sıvasız halde 1922'ye kadar kullanım görmüştür. Daha sonra terk edilen yap1 1954'te Panagia ile birlikte Nuri Zarplı İlköğretim Okulu için inşa malzemesi temin etmek maksadıyla yıktırılmıştır (Onay, 2000a: 46-47). Öte yandan Psarros (2017: 347-349), Fritz Mraz'ın yaklaşık 1900 ve Ali Onay'ın 1930 tarihli iki eski fotoğrafından yola çıkarak kilisenin genel mimari özelliklerini tutarlı bir şekilde tanımlamıştır. Buna karşın yalnızca Drakos'un (1888: 19) ifadesini baz alarak yapıyı 1882'ye tarihlendirilmiştir. Dahası, 19. yüzyılın sonları itibariyle Ayvalıklı ünlü bir mimar olan ve yörede neoklasik üslupta birkaç önemli kilisede imzası bulunan Emmanuel Kounas'in bir diğer eseri olabileceğini iddia etmiştir. Bu durumda 1896 'da I. Theoklitos tarafindan yeniden inşa ettirilmiş kubbeli yapı, tarihsel bağlamda II. Paisios tarafından 1882 'de yeniden inşa ettirilmiş bazilika gibi yorumlanmıştır. 1895-1896 tarihli arşiv belgeleri ihmal edildiği üzere kilisenin mimarlık tarihi eksik kalmış ve kalfa Onoufrios Kouvaras tarafından 1895 'te tasarlanmış bina, yüzeysel ve hatalı bir şekilde Emmanuel Kounas'a atfedilmiştir.

Yaklaşık 1900 civarına ve 1930 'a tarihlenen iki eski fotoğrafta da bire bir aynı yapılar gözüktügü üzere Agios Panteleimon'un 1915'te son bir yeniden inşa daha geçirip geçirmediği henüz tam anlamıyla ortaya konamamıştır (Şek. 19). Bunun yanında 19. yüzyılın sonunda arka arkaya yeniden inşa edilmesi ise Panagia için öne sürüldüğü üzere sık gerçekleşmiş depremlerle ilgili olmalıdır (Soysal vd., 1981). Patrik VII. Anthimos'un 14 Haziran 1895 tarihli dilekçesinde de o dönem itibariyle en son 1882 'de inşa edilmiş Agios Panteleimon'un zamanla harap olduğu kaydedilmişti (BOA, ŞD, 2661-55, H-28-05-1313). Panagia'ya benzerlik gösteren bir diğer ilginç 
nokta da, Agios Panteleimon'un 1895 tarihli planında portikonun üzerinde gözüken incelikli pencere tasarımının görünüşte uygulanmayışı ve burada çok daha basit bir pencere düzenlemesinin tercih edilişidir. Dolayısıyla 1895 tarihli yeniden inşa planındaki yapıyla, yaklaşık 1900 ve 1930 tarihli fotoğraflarda gözüken kilise tam olarak eşleşmemektedir. Bu durum da yine Tsitimaki ve Shariat-Panahi (2014) tarafından ortaya konduğu üzere, Midilli yöresindeki Rumların 19. yüzyıla kadarki kilise inşa veya tamir faaliyetlerinde, onaylanmış planlardan farklı inşalar gerçekleştirmek suretiyle kanunları ihlal etmeleriyle ilintili olabilir.

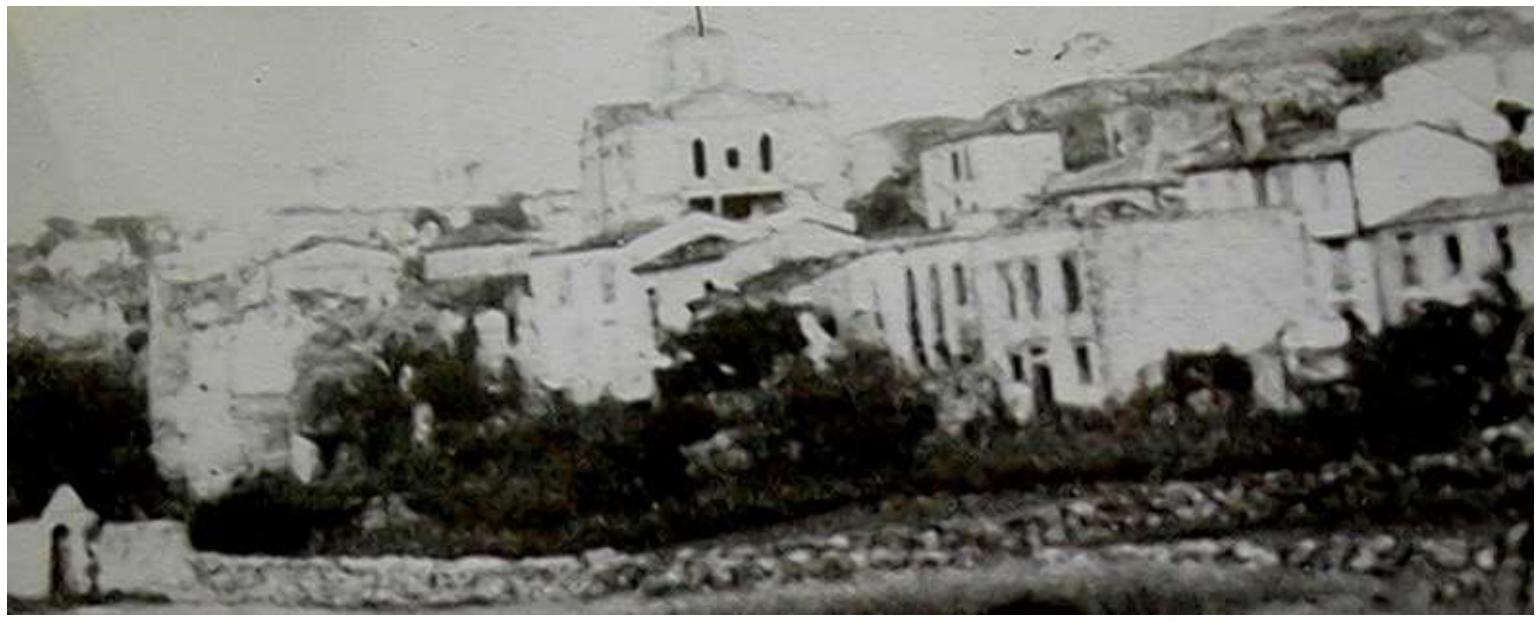

Şekil 19: 1930'da Agios Panteleimon'un batıdan görünümü (Ali Onay Kişisel Arşivi).

Agios Panteleimon'un narteks, naos ve apsis bölümleri günümüzde zemin seviyesinden yaklaşık 1-2 metre yüksekliğe kadar korunmuştur. Yüksekçe bir enkaz ve bitki örtüsü, arsanın tamamını kaplamaktadır. Örtü sistemine ait karışık malzemeden bazı yıkık parçalar, alanın genelinde görülebilmektedir. Kilise binası karakteristik pembemsi renge sahip yöresel Sarımsak taşından inşa edilmiştir. Panagia'nın da avlu duvarlarında görülen yerel duvar işçiliğine sahiptir. Aralara yerleştirilmiş ufak ve yassı parçalar ile düzenli sıralar oluşturan kabaca yontulmuş bloklar, dayanıklı bir tür kireç harcıyla birbirine tutturulmuştur. Ayrıca avlunun batı kesiminde, önceden papazların kullandığı müştemilattan olan iki katlı ve sonradan tuğladan eklemelerle birtakım değişikliklere uğramış harap bir konut bulunmaktadır. Kilisenin halen mevcut apsis bölümü, derme çatma bir kümes ile dıştan örtülmüş̧ür ve avlunun ortasında da modern bir baraka yer almaktadır (Şek. 20-21-22). 


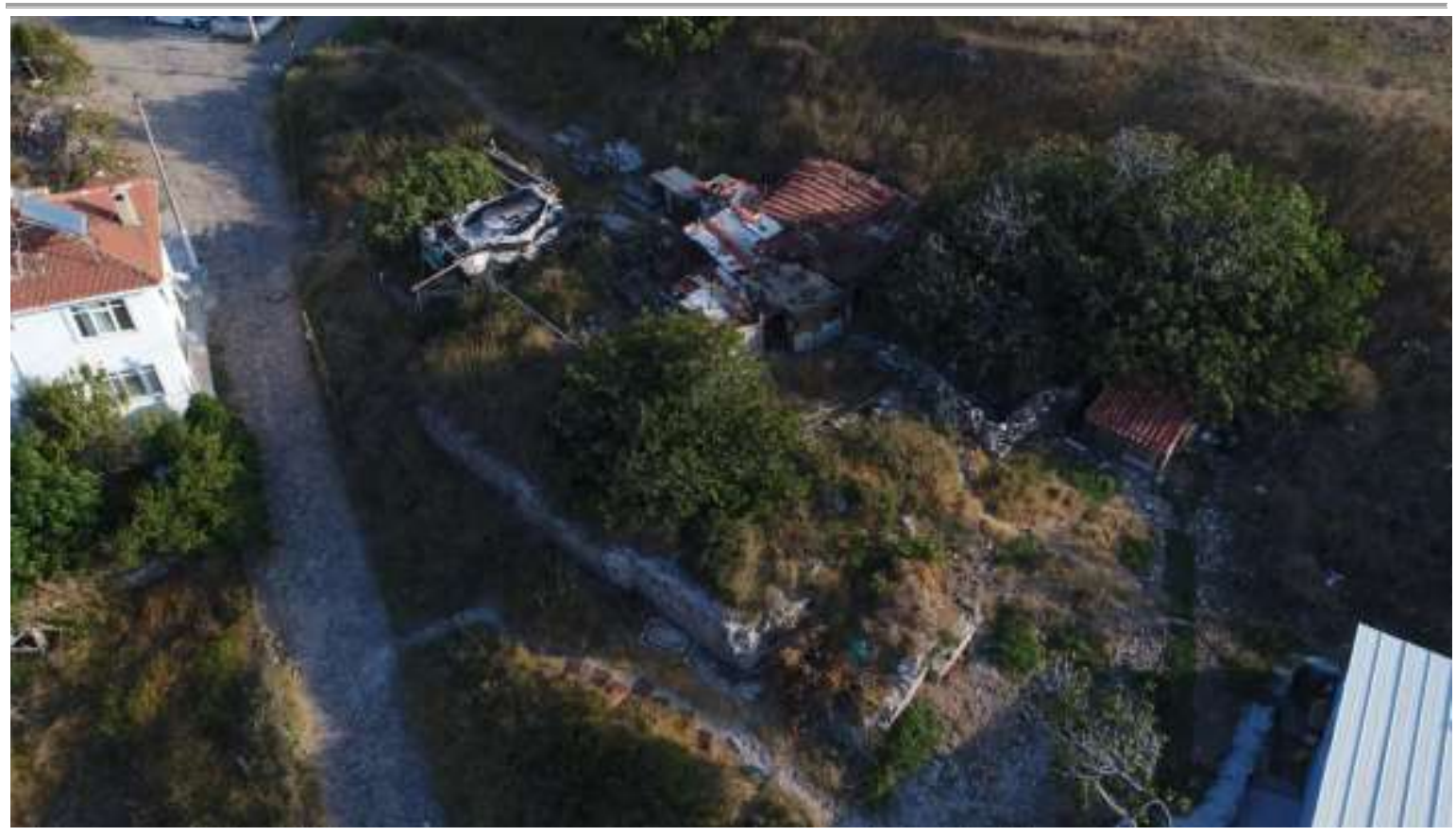

Şekil 20: Agios Panteleimon'un kalıntısının kuzeybatıdan görünümü (KEAM, 2020).

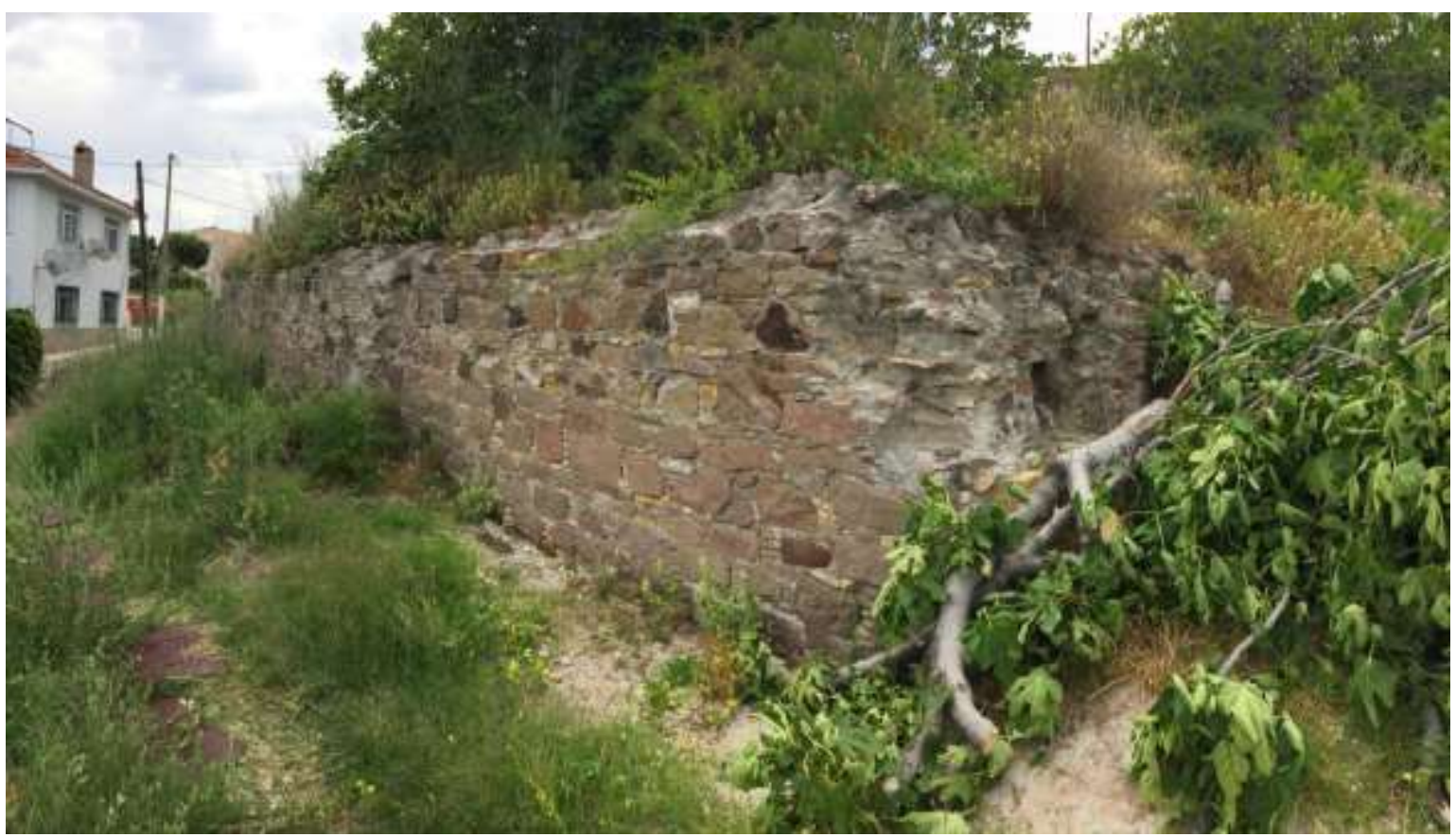

Şekil 21: Agios Panteleimon'un kalıntısının kuzeybatıdan görünümü (KEAM, 2020). 


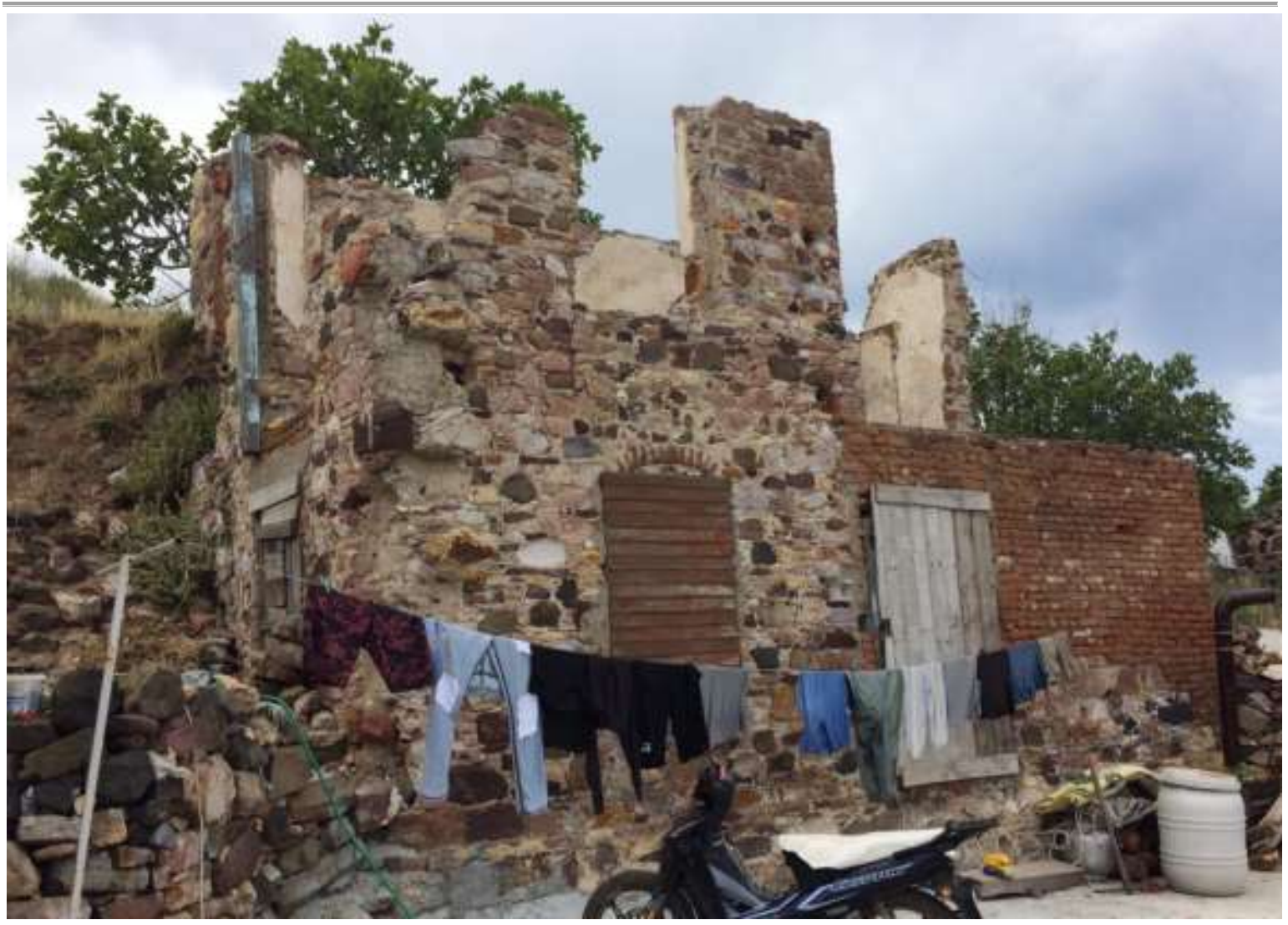

Şekil 22: Agios Panteleimon'un avlusundaki harap konut (KEAM, 2020).

\section{Güncel Korunma Durumu}

Panagia ve Agios Panteleimon Kiliselerinin arsaları, Cunda Adası tarihi yerleşim merkezinin eski koruma amaçlı imar planı sınırları içerisinde kalmaktaydı. Bursa Kültür ve Tabiat Varlıklarını Koruma Kurulu'nun (BKTVKK) 22 Ocak 1994 tarihli ve 3622 sayılı kararıyla onaylanmış 1/1000 ve 1/500 ölçekli plan (Ayvalık Belediyesi, 1994; Yaylal1-Gençer, 2006), her iki kiliseyi de tamamen ihmal etmişti. Görünüşe bakılırsa literatürdeki oldukça kısıtlı bilgi, eksik kalmış tescil envanteri ve birincil kaynaklarla takviye edilmemiş bir saha araştırması buna neden olmuştu. 1994 tarihli koruma amaçlı imar planına göre Panagia'nın boş olarak varsayılmış arsası öneri konut alanı olarak belirlenirken Agios Panteleimon'un arsası ise park olarak planlanmış; iki yapının da kalıntılarına yönelik koruma namına hiçbir önlem alınmamıştı.

Daha sonra 23 Kasım 2018 tarihinde, Balıkesir 1. İdare Mahkemesi'nin 2017/1352 sayıl1 karara dayanan 2018/1635 sayılı kararı ile 1994 tarihli Cunda koruma amaçlı imar planı iptal edilmiştir. Balıkesir Kültür ve Tabiat Varlıklarını Koruma Bölge Kurulu, geçiş dönemi koruma esaslarını ve kullanım şartlarını ancak 11 Eylül 2020 tarihinde 2244, 2245 ve 2246 sayılı kararlarla belirlemiş, lakin Cunda'daki herhangi bir kamu işi ya da imar izni yine bu kurulun kendi takdirine bırakılmıştır (BBB, 29.09.2020/642; Salgın, 2020). Cunda'nın yeni koruma amaçlı imar planına yönelik çalışmalar hala sürmektedir. Bugün itibariyle, Panagia ve Agios Panteleimon Kiliselerinin arsalarında bulunan çok katmanlı mimari mirasın, 1994 tarihli "koruma" amaçlı imar planının belirlemiş olduğu gibi konut veya park alanı olmaktan şans eseri kurtulduğu söylenebilir. Buralardaki kültür mirası, yoğun zemin çalışmaları sonucu tamamen tahrip olabilirdi (Şek. 23). 


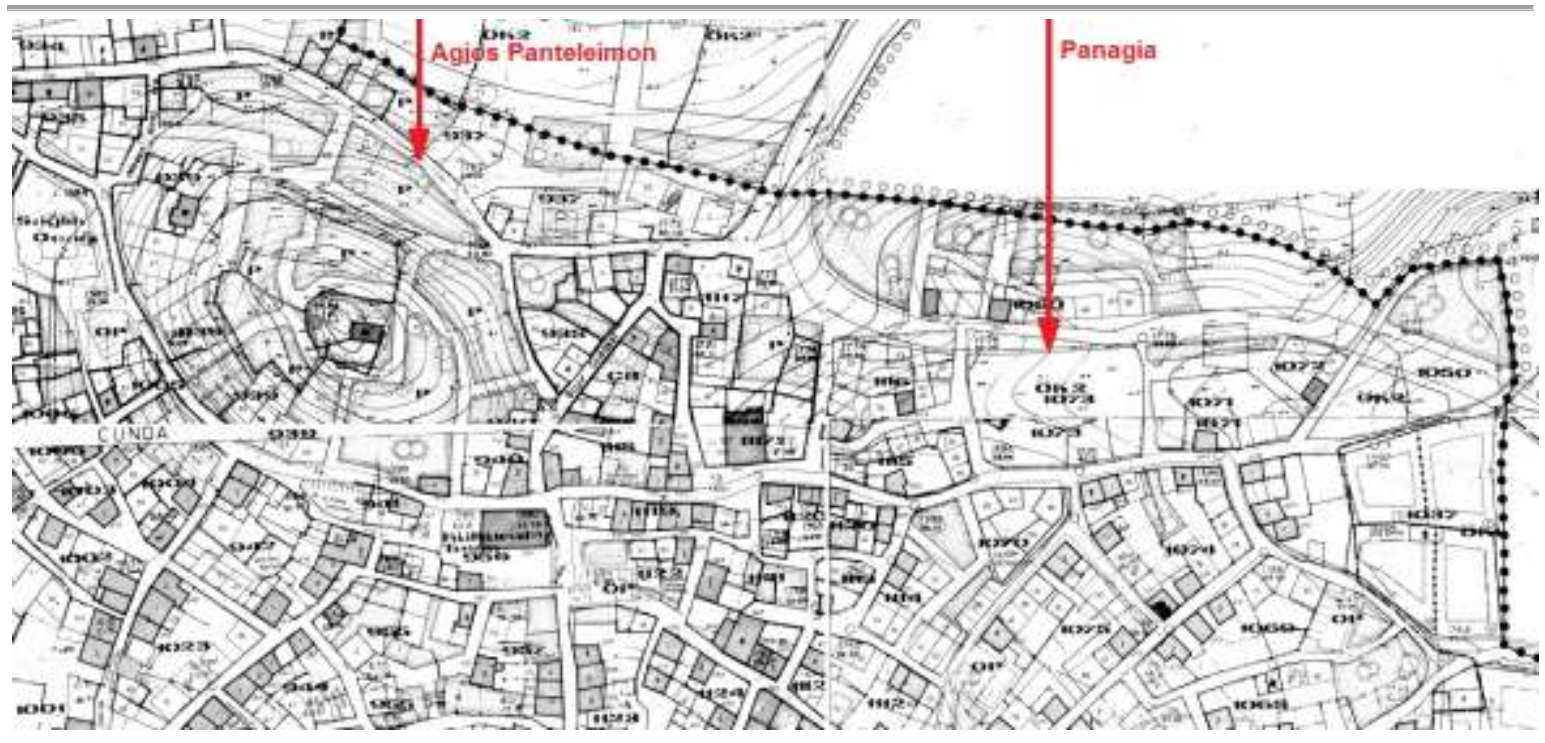

Şekil 23: Agios Panteleimon ve Panagia Kiliselerinin 1994 tarihli koruma amaçlı imar planında sırayla park ve öneri konut alanı olarak planlanmış parselleri (Ayvalık Belediyesi, 1994).

Bununla birlikte 23 Ocak 2020 tarihinde, Kaptan vd. (2019)'nin yayımladığı eski fotoğrafları dikkate alan bir araştırma sonucu Panagia Kilisesi'nin arsası, Balıkesir Kültür ve Tabiat Varlıklarını Koruma Bölge Kurulu'nun 29 Ocak 2020 tarihli ve 1815 sayılı kararı sonucu 2. anıtsal ve 1. çevresel koruma dereceleriyle tescil edilmiştir. Lakin Ayvalık Belediyesi'ne ait olup Bakkal Sokak'tan mahreç alan Mithatpaşa Mahallesi 1073 ada 1 parselde bulunan arsadaki kalıntılara yönelik detaylı bir çalışma yapılmamıştır. Yüzeyde mevcut kalıntıların basit bir tanımı yapıldıktan sonra kabaca 19. yüzyılın ilk yarısına tarihlendirilmiş Panagia Kilisesi'nin mimari planı ise belirsiz olarak nitelendirilmiştir (BKTVKBK, 29.01.2020/1815).

Öte yandan Agios Panteleimon Kilisesi'nin günümüzde Maden Caddesi'nden mahreç alan Namıkkemal Mahallesi 1025 adadaki hazine arazisi 1 parsel ve özel mülk 2 parsel içerisinde kalan arsası ise Mart 2021 itibariyle herhangi bir resmi koruma kararına tabi değildir. Görüldüğü üzere her iki kiliseye ilişkin Ayvalık ve Cunda ilgisindeki bilimsel literatürde olduğu gibi ulusal düzeydeki koruma kararlarında da eksiklikler vardır. Cunda'nın tarihi yerleşim merkezi için bir koruma amaçlı imar planının hala olmayışı ve tescil envanterindeki eksiklikler, bahis konusu anıt eserlerin korunma statüsüne yönelik bir hayli belirsiz bir durum doğurmaktadır. Kiliselerin arsaları tamamen erişilebilir durumdadır. Vandalizme yönelik herhangi bir önlem alınmamıştır ve bu ciddi tehdit Cunda kültür mirasına güncel olarak büyük zarar vermektedir (Kaya, 2021). Özellikle de hala tescilsiz durumdaki Agios Panteleimon Kilisesi'nin kalıntıları, doğal olarak yeni imar çalışmalarına karşısında da savunmasız vaziyettedir (Şek. 24).

Dahas1, Agios Panteleimon ve Panagia ile ilgisi henüz belirsiz olmakla birlikte, dikkate değer bir duruma Midilli'deki üç örnek üzerinden değinmek yerinde olacaktır. Mantamados, Pappados ve Kagiani yerleşimlerinde bulunan Taksiarkhis kiliselerinde, Geç Bizans Dönemine tarihlenen ilk kiliselerde bulunan Başmelek Mikail ikonalarının yer aldığı duvar parçaları, depremler nedeniyle yüzyıllar boyunca aynı arsalarda farklı temeller üzerinde defalarca yeniden inşa edilmiş kilise yapılarının içerisinde, bağımsız mimari unsurlar şeklinde günümüze kadar dikkatlice korunmuştur (Konstantinidi \& Tsitimaki, 2018). Bu bağlamda benzer bir korunmuşluk durumu, Panagia ve Agios Panteleimon'un daha önceki ve en son yapılarına yönelik ileriki çalışmalar esnasında dikkate alınması gereken bir ihtimaldir. 


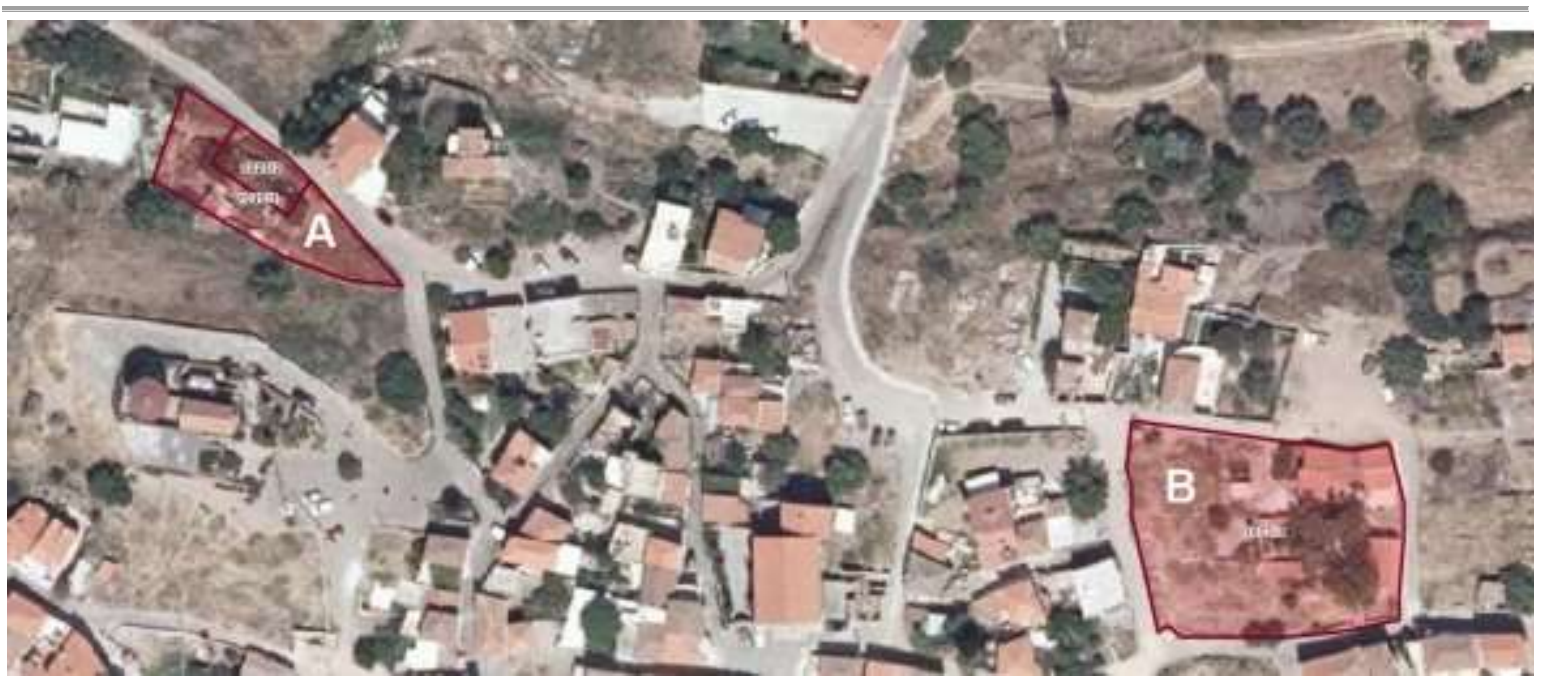

Şekil 24: Agios Panteleimon (A) ve Panagia (B) Kiliselerinin parselleri (Tapu ve Kadastro Genel Müdürlüğü Parsel Sorgulama Uygulaması, 2021).

\section{Sonuç ve Değerlendirme}

Arşiv belgelerinin ve mevcut birincil kaynakların titizlikle incelenmesi sonucunda Cunda Adası'ndaki yıkık Panagia ve Agios Panteleimon Kiliselerinin literatür tarafindan ihmal edilmiş mimarlık tarihi önemli ölçüde detaylandırılmış olup kronolojilerinin önceden sonuçlandırılandan oldukça farklı olduğu görülmüştür. Panagia Kilisesi ilgisinde, mevcut çan ve birincil kaynaklarla karşılaştırmalı olarak 1863 tarihli ilk inşa rivayeti dikkatlice incelendiğinde, bunun çan üzerindeki yazıttan türetilmiş bir şehir efsanesi olduğu ve nihai yeniden inşanın 1883 'te gerçekleştiği ortaya konmuştur. 1863 ise Panagia'nın ilk çan kulesinin inşa yılıdır ve çanın yazıtının doğruladığı bilgi aslında budur. Benzer şekilde, Agios Panteleimon Kilisesi'nin de son yeniden inşası 1882'de değil 1896 'da gerçekleştirilmiştir. Ayrıca daha önce varsayıldığ 1 üzere Emmanuel Kounas değil, kalfa Onoufrios Kouvaras tarafından tasarlanmıştır.

Eski fotoğraflarda tespit edilen kilise yapılarıyla yeniden inşa planlarında mevcut olanlar arasında kayda değer mimari uyumsuzluklar fark edilmiştir. Ortaya konan her iki kilise binasının da ön cephe düzeni, yeniden inşa planlarında gösterilenden farklıdır. Dahası, çan kulesine hiç değinilmeden Panagia'nın bir önceki binasıyla aynı biçimde tekrardan inşa edileceği belirtilmiş, lakin netice olarak yapıya entegre edilmiş yeni ve yüksek bir çan kulesi inşa edilmiştir. Literatüre göre Cunda'nın yakınındaki Midilli Adası'nda 19. yüzyıla kadar Rumlar kilise onarımı ve yeniden inşaları esnasında kanunları sıkça ihlal etmişti. Arşiv belgelerine göre de bir keresinde Cunda'da inşaat izni olmadan bir kilise inşa edilmişti. Panagia ve Agios Panteleimon kiliselerinde belirlenmiş mimari uyumsuzluklar da bu hadiseler üzerinden izah edilebilir.

Aynı arsalarda en az üçer kez inşa edilmiş Panagia ve Agios Panteleimon'un eski kilise binaları ile en sonuncular arasındaki arkeolojik çok katmanlılığın düzeyi henüz belli değildir. Lakin sırayla 1883 ve 1896 'da yeniden inşa edilmiş son kilise binalarının taşıyıcı duvarları, her iki arsada da eski yapılara ait temellerin üzerine konumlandırılmayıp kayda değer miktarda kaydırıldığı üzere, önceki kilise yapılarına ait temel kalıntılarının daha alt kotlarda bir dereceye kadar korunmuş olması yüksek bir ihtimaldir. Bu hususta dikkate alınması gereken bir diğer ihtimal de Midilli'den örneklerde görüldüğü üzere, yeniden inşa edilen kiliselerin içerisinde eski kiliselere ait mimari bölümlerin bilinçli olarak korunmuş oluşudur. Panagia ve Agios Panteleimon'un en son yapılarının ise beraberindeki diğer bölümlerle birlikte yüksek moloz ve bitki örtüsünün altında büyük oranda korunduğu kesindir, zira 1954'teki son yıkımları kapsamlı bir arazi tesviyesinden ziyade yap1 malzemesi temin etmeye yönelikti. Ayrıca papazlar için ek binalar, avlu döşemeleri, Panagia'nın ek 
şapeli ve özellikle de buradaki hem kutsal kabul edilmiş hem de kent altyapısı için önem taşımış ayazma kompleksinin kalıntıları da ileriki çalışmalarda göz önünde bulundurulmalıdır.

Ayrıca her iki kilisenin de korunma durumlarının geçmişte çok kritik düzeyde eksikliğe sahip olduğu tespit edilmiştir. Örneğin 1994 tarihli Cunda koruma amaçlı imar planı tarafindan Panagia'nın arsası öneri konut alanı, Agios Panteleimon'un arsası ise park olarak planlanmıștı. Yakın zamanda iptal edildiği üzere günümüzde bir koruma amaçlı imar planından yoksun Cunda'ya yönelik yeni şehircilik çalışmalarında bu kez her iki kilisenin de hassasiyetle dikkate alınması gerekmektedir. Bunun yanında Panagia'nın mevcut tescil envanteri geliştirilmeye ihtiyaç duymaktadır. Halihazırda tescilsiz durumdaki Agios Panteleimon içinse risk daha büyük olduğu üzere ivedi bir tescil ve detaylı bir belgeleme çalışmasının gerekliliği fark edilmiştir.

Cunda tarihi kent merkezinde yenilenerek kültürel ve turistik kullanımlarla yeniden işlev kazandırılmış Taksiarkhis Kilisesi ve Agios Ioannis Şapeli ile geleneksel dokuyu yansıtan sivil mimarlık örnekleri, yaratılan nitelikli değer sonucu yerel turizm ve ekonomiye önemli katkı sağlamıştır. Gerekli koruma kararları sonrasında Panagia ve Agios Panteleimon kiliselerine ait korunmuş kalıntılar, arkeoloji biliminin ilgisindeki çalışmalarla dikkatlice gün yüzüne çıkartılabilir. Dijital belgeleme yöntemleri ve sanal rekonstrüksiyon gibi teknolojik gelişmeler yardımıyla her iki parsel de ileride çok katmanlı karaktere sahip tematik modern arkeoloji açık hava müzelerine dönüştürülebilinir.

\section{Kaynakça}

\section{A- Arşiv Belgeleri}

Ayvalık Belediyesi (1994, 22 Ocak). Alibey Adası Kentsel Sit Alanı Koruma Amaçlı İmar Planı, $1 / 500 \& 1 / 1000$ (Müellif: Dokuz Eylül Üniversitesi, Prof. Dr. M. Çınar Atay).

Balıkesir Kültür ve Tabiat Varlıklarını Koruma Bölge Kurulu (BKTVKBK). [Balıkesir İli Ayvalık İlçesi Mithatpaşa Mahallesi 1070-1073 Ada 1-1 Parsel Tescil Fişi]. (29.01.2020/1815).

Devlet Arşivleri Başkanlık Osmanlı Arşivi (BOA), Ali Emiri Ahmed II (AE.SAMD.II), 11-1154, H-24-10-1105.

Devlet Arşivleri Başkanlığı Osmanlı Arşivi (BOA). Bâb-ı Âlî Evrak Odası (BEO), 841-63071, H13-04-1314.

Devlet Arşivleri Başkanlık Osmanlı Arşivi (BOA). Bab-ı Asafi Divan-ı Hümayun Sicilleri Mühimme Defterleri (A.DVNS.MHM.d), 47-284, H-20-04-990.

Devlet Arşivleri Başkanlık Osmanlı Arşivi (BOA). Bab-ı Asafi Divan-ı Hümayun Sicilleri Mühimme Defterleri (A.DVNS.MHM.d), 110-935, H-20-05-1109.

Devlet Arşivleri Başkanlığı Osmanlı Arşivi (BOA). Dâhiliye Mektubî Kalemi (DH.MKT), 287-38, H-25-03-1312.

Devlet Arşivleri Başkanlığı Osmanlı Arşivi (BOA). Dâhiliye Mektubî Kalemi (DH.MKT), 308-75, H-16-05-1312.

Devlet Arşivleri Başkanlığı Osmanlı Arşivi (BOA). Hatt-ı Hümâyun (HAT), 901-39605, H-29-121240.

Devlet Arşivleri Başkanlık Osmanlı Arşivi (BOA). Hatt-ı Hümâyun (HAT), 942-40662, H-25-091236. 
Devlet Arşivleri Başkanlık Osmanlı Arşivi (BOA). İbnülemin Bahriye (IE.BH), 13-1183, H-29-121130.

Devlet Arşivleri Başkanlık Osmanlı Arşivi (BOA). İbnülemin Vaklf (IE.EV), 18-2194, H-13-111076.

Devlet Arşivleri Başkanlığı Osmanlı Arşivi (BOA). Irâde Adliye ve Mezâhib (İ.AZN), 21-25, H28-03-1314.

Devlet Arşivleri Başkanlığı Osmanlı Arşivi (BOA). Irâde Dahiliye (İ.DH), 875-69842, H-20-031300.

Devlet Arşivleri Başkanlığı Osmanlı Arşivi (BOA). Maliyeden Müdevver Defterler (MAD.d), 14773, H-29-09-1011.

Devlet Arşivleri Başkanlığı Osmanlı Arşivi (BOA). Şûrâ-yı Devlet (ŞD), 2351-31, H-29-06-1312.

Devlet Arşivleri Başkanlığı Osmanlı Arşivi (BOA). Şûrâ-yı Devlet (ŞD), 2661-55, H-28-05-1313.

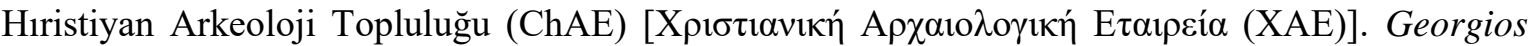
Lampakis Koleksiyonu, 6027.

Mimar Sinan Güzel Sanatlar Üniversitesi (MSGSÜ) Kuzey Ege Arkeoloji Araştırmaları Uygulama ve Araştırma Merkezi (KEAM) Fotoğraf Arşivi.

Ali Onay Kişisel Arşivi, Ayvalık.

Deniz Eren Kişisel Arşivi, Ayvalık.

\section{B- Kitap, Makale, Tez}

Ağır, A. (2010). İstanbul'un eski Venedik yerleşimi ve dönüşümü. İstanbul Araştırmaları Enstitüsü.

Ali Saib. (1886). Coğrafya-i mufassal: Memalik-i Devlet-i Osmaniye. Matbaa-i Ebüzziya.

Anonim (1995). 166 numaralı muhâsebe-i Vilâyet-i Anadolu defteri (937/1530) - Hudâvendigâr, Biga, Karesi, Saruhân, Aydın, Menteşe, Teke ve Alâiye livâları. Başbakanlık Devlet Arşivleri Genel Müdürlüğü Osmanlı Arşivi Daire Başkanlığı.

Balıkesir Valiliği İl Kültür ve Turizm Müdürlüğü. (2010). Balıkesir kültür envanteri taşınmaz kültür varlıkları. Zeytin Yayın Grubu.

Cezâyir-i Bahr-i Sefîd Vilâyeti. (1884). Cezâyir-i Bahr-i Sefìd Vilâyeti salnâmesi. Cezâyir-i Bahr-i Sefîd Vilâyeti Matbaasi.

Cezâyir-i Bahr-i Sefîd Vilâyeti. (1885). Cezâyir-i Bahr-i Sefíd Vilâyeti salnâmesi. Cezâyir-i Bahr-i Sefîd Vilâyeti Matbaası.

Cezâyir-i Bahr-i Sefîd Vilâyeti. (1886). Cezâyir-i Bahr-i Sefìd Vilâyeti salnâmesi. Cezâyir-i Bahr-i Sefîd Vilâyeti Matbaas1.

Cezâyir-i Bahr-i Sefîd Vilâyeti. (1893). Cezâyir-i Bahr-i Sefìd Vilâyeti salnâmesi. Cezâyir-i Bahr-i Sefîd Vilâyeti Matbaas1.

Cezâyir-i Bahr-i Sefî̀d Vilâyeti. (1898). Cezâyir-i Bahr-i Sefíd Vilâyeti salnâmesi. Cezâyir-i Bahr-i Sefîd Vilâyeti Matbaasi.

Cezâyir-i Bahr-i Sefîd Vilâyeti. (1903). Cezâyir-i Bahr-i Sefíd Vilâyeti salnâmesi. Cezâyir-i Bahr-i Sefîd Vilâyeti Matbaasi.

Chatzapostolis, I. E., Papacharalampous, E., Paneras, D. N. \& Kouvaras, A. D. (1913). 'Eк $\varepsilon \varepsilon \sigma \iota \varsigma$

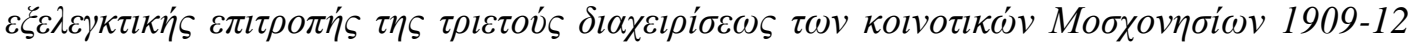


[Ékthesis exelenktikís epitropís tis trietoús diacheiríseos ton koinotikón Moschonisíon 1909-12]. Moskhonisi.

Clogg, R. (1972). Two accounts of the Academy of Ayvalik (Kydonies) in 1818-1819. Revue des Etudes Sud-Est Éuropéennes, 10(4), 633-667.

Cuinet, V. (1892). La Turquie d'Asie: Géographie administrative, statistique, descriptive et raisonnée de chaque (Cilt 1). Ernest Leroux.

Demirel, M. (2005). Construction of churches in Ottoman provinces. Imber, C., Kiyotaki, K. \& Murphey, R. (Ed.), Frontiers of Ottoman studies: State, province, and the west (Cilt 2, pp. 211-224). I.B.Tauris.

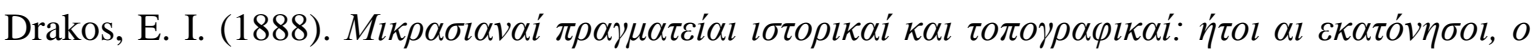

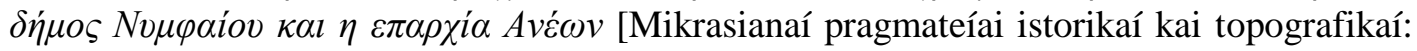
ítoi ai Ekatónisoi, o dímos Nymfaíou kai i eparchía Anéon]. Atina.

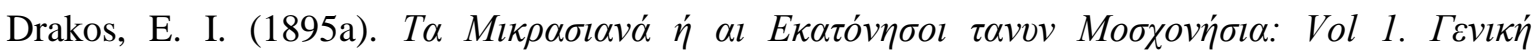

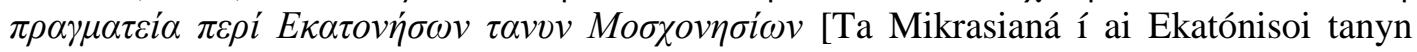
Moschonísia: Vol 1. Genikí pragmateía perí Ekatoníson tanyn Moschonisíon]. Atina.

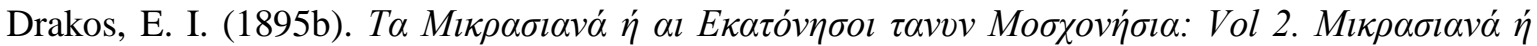

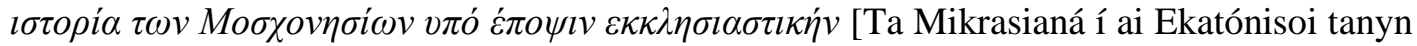
Moschonísia: Vol 2. Mikrasianá í istoría ton Moschonisíon ypó épopsin ekklisiastikín]. Atina.

Gümüş, M. (2008). Anayasal meşrûtî yönetime medhal: 1856 Islahat Fermanı'nın tam metin incelemesi. Bilig, 47, 215-240.

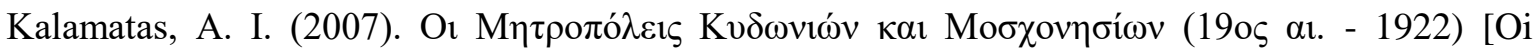
Mitropóleis Kydonión kai Moschonisíon (19os ai. - 1922)]. Kitromilides, P. M., \&

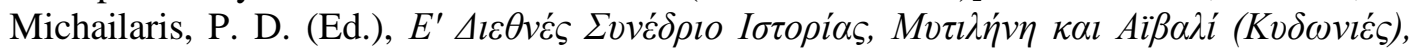

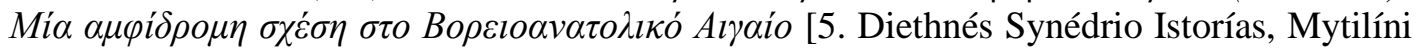
kai Aïvalí (Kydoniés), Mía amfídromi schési sto Voreioanatolikó Aigaío] (pp. 39-50). Institute for Neohellenic Research.

Kaptan, M. S., Ergelen, F. \& Soylu, M. M. (2019). Yılların içinden Ayvalık. Kazmaz Matbaacılık.

Karaca, Z. (2008). Ístanbul'da Tanzimat öncesi Rum Ortodoks kiliseleri. Yap1 Kredi Yayınları.

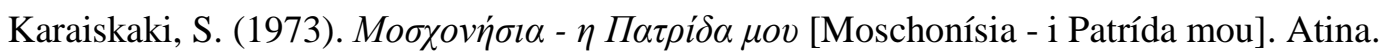

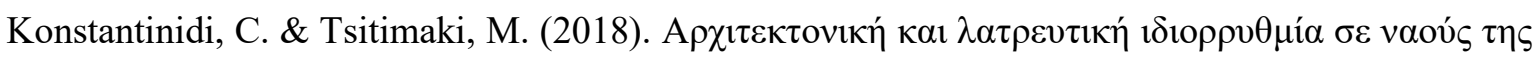

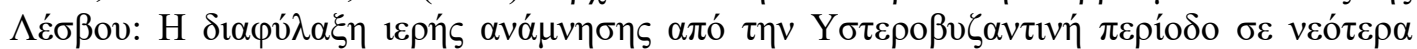
$\pi \rho о \sigma \kappa v v \eta \tau \alpha ́ p ı$ [Architektonikí kai latreftikí idiorrythmía se naoús tis Lésvou: I diafýlaxi ierís anámnisis apó tin Ysterovyzantiní período se neótera proskynitária]. Korres, M.,

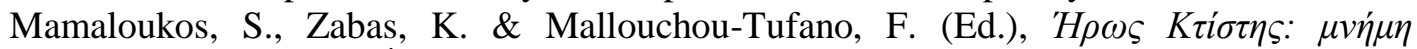

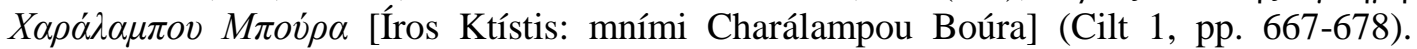
Ekdotikos Oikos Melissa.

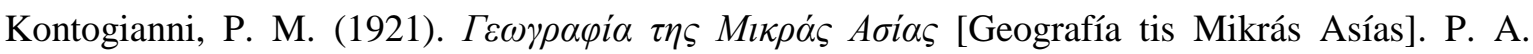
Petrakos.

Koyuncu, A. (2014). Osmanlı Devleti'nde kilise ve havra politikasına yeni bir bakış: Çanakkale örneği. Çanakkale Araştırmaları Türk Yıllı̆̆ı , 16, 35-87.

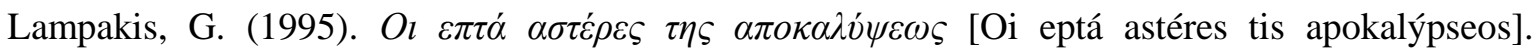
Pournaras P. S. 
Mutaf, A. (2003). Salnâmelere göre Karesi (1847-1922). Zağnos Kültür ve Eğitim Vakfı.

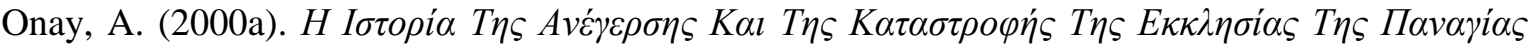

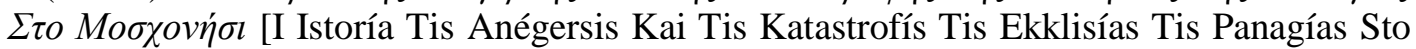
Moschonísi]. Livani.

Onay, A. (2000b). Panayia Kilisesi'nin öyküsü. İskenderiye Yazıları, 24 (Ocak-Şubat 2000).

Onay, A. (2010). Panayia Kilisesi ve çan. Papalina, 22, 12.

Ortaç, H. (2010). Batı Anadolu'da bir büyük toprak sahibi Levanten: Baltacı Manolaki. Tarih Incelemeleri Dergisi, 25(1), 319-336.

Özgen, H. M. (2017). Kuzey Ege Arkeoloji Araştırmaları ve Uygulama Merkezi (KEAM) Adramytteion ve egemenlik alanı çalışmaları 2015 - 2016. Türk Eskiçağ Bilimleri Enstitüsü Haberler, 43, 47-59.

Pîrî Reis (2013). Kitâb-ı Bahriye (B. Özükan, Ed.). Boyut Yayıncılık.

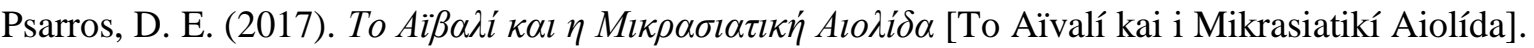
MIET.

Sevim, S. (1993). XVI. yüzyılda Karasi Sancă̆g (tahrir defterlerine göre) [Yayımlanmamış doktora tezi]. Ankara Üniversitesi.

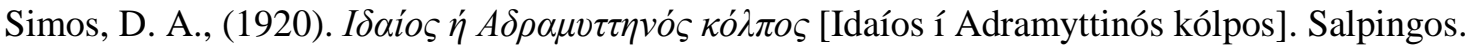

Soysal, H., Sipahioğlu, S., Kolçak, D. \& Altınok, Y. (1981). Türkiye ve çevresinin tarihsel deprem kataloğu (M.Ö. 2100-M.S. 1900). TÜBİTAK.

Şahin Güçhan, N. (2008). Tracing the memoir of Dr Şerafeddin Magmumi for the urban memory of Ayvalik. METU Journal of the Faculty of Architecture, 25(1), 53-80.

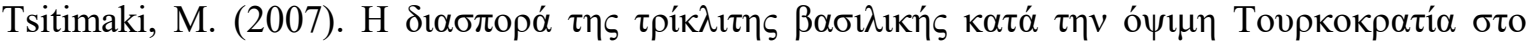

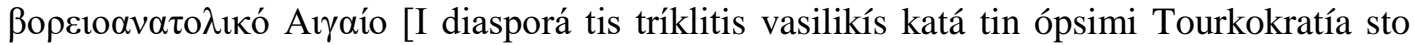
voreioanatolikó Aigaío]. Kitromilides, P. M., \& Michailaris, P. D. (Ed.), E' $\Delta \imath \varepsilon \theta v \varepsilon ́ s$

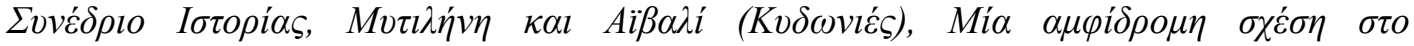

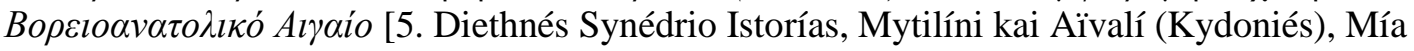
amfídromi schési sto Voreioanatolikó Aigaío] (pp. 481-496). Institute for Neohellenic Research.

Tsitimaki, M. \& Shariat-Panahi, S. M. T. (2014). Transgression of law regarding church-building (17 $17^{\text {th }} 19^{\text {th }}$ Century): The case of Lesvos. Sariyannis, M. (Ed.), New Trends in Ottoman Studies, Papers presented at the 20 $0^{\text {th }}$ CIÉPO Symposium, Rethymno, 27 June-1 July 2012 (pp. 1123-1140). University of Crete \& FORTH.

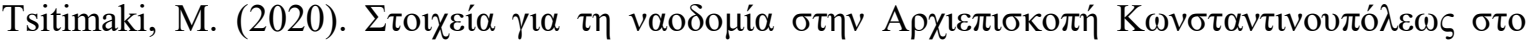

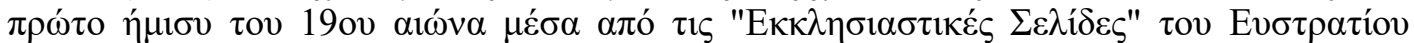
$\Delta \rho \alpha ́$ Kov [Stoicheía gia ti naodomía stin Archiepiskopí Konstantinoupóleos sto próto ímisy

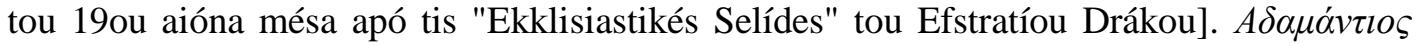

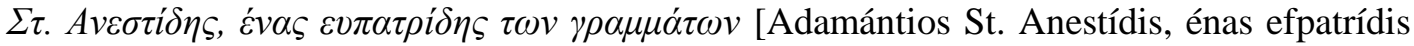

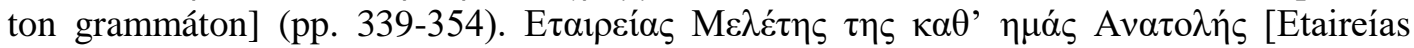
Melétis tis kath' imás Anatolís].

Turan, G. (2008). Mübadelede Ayvalık [Yayımlanmamış yüksek lisans tezi]. Dokuz Eylül Üniversitesi.

Uygur, M. \& Erim, H. (1948). Ayvalık tarihi. Güney Matbaacılık ve Gazetecilik. 
Ünver, M. (2012). Midilli Adası'nın idari ve sosyo-ekonomik yapısı (1876-1914) [Yayımlanmamış doktora tezi]. İstanbul Üniversitesi.

Yaylalı-Gençer, C. İ. (2006). Cunda Adası'nda tarihi çevre koruma ve sthhileştirme çalışması [Yayımlanmamış yüksek lisans tezi]. İstanbul Teknik Üniversitesi.

Yaylalı-Gençer, C. İ. (2007). Cunda Adası'nda tarihi çevre koruma ve sıhhileştirme çalışması. Mimar.ist, 24(2007/2), 82-88.

Yaylal1-Gençer, C. İ. (2014). Tourism and urban preservation: A case study on Cunda Island. Architecture \& Science, 1(2), 67-78

Yorulmaz, A. (2004). Ayvalık'ı gezerken. Dünya Yayıncılık.

\section{C- İnternet Kaynakları}

Balıkesir Büyükşehir Belediyesi (BBB). 2020 yılı Ağustos ayı olağan toplantısı 2. birleşiminde alınan meclis karar özetleri (29.09.2020/642). https://www.balikesir.bel.tr/kurumsal/ belediye-meclisi/meclis-kararlari

Google Haritalar. https://www.google.com/maps

Kaya, K. (2021, 3 Ocak). Balıkesir'de 250 yıllık manastır şapeli defineci kazıları nedeniyle yıkıldı. Hürriyet. https://www.hurriyet.com.tr/gundem/balikesirde-250-yillik-manastir-sapelidefineci-kazilari-nedeniyle-yikildi-41704956

Salgın, S. (2020, 8 Aralık). Ayvalık'ın nazım imar planlarının iptal edilmesi kaygılandırıyor. Medya Ayvalı. $\quad$ https://medyaayvalik.com/2020/12/08/ayvalikin-nazim-imar-planlarinin-iptaledilmesi-kaygilandiriyor/

Tapu ve Kadastro Genel Müdürlüğü Parsel Sorgulama Uygulamas1. https://parselsorgu.tkgm.gov.tr/ 